\title{
The 3D conductive thermal field of the North Alpine Foreland Basin: influence of the deep structure and the adjacent European Alps
}

\author{
Anna M. Przybycin ${ }^{1,3^{*}}$, Magdalena Scheck-Wenderoth ${ }^{1,2}$ and Michael Schneider ${ }^{3}$
}

*Correspondence:

anna-maria.przybycin@

gfz-potsdam.de

${ }^{1}$ Department 4 Chemistry

and Material Cycles,

Section 4.4 Basin Analysis,

German Research

Centre for Geoscience

GFZ-Helmholtz Centre

Potsdam, Telegrafenberg,

14473 Potsdam, Germany

Full list of author information

is available at the end of the article

\begin{abstract}
We use a databased lithospheric-scale 3D structural model of the Molasse Basin area and the adjacent part of the Alpine orogen to calculate the present-day 3D thermal field of this continental collision zone. With our work we contribute to the understanding of the temperature distribution and the existence of pronounced positive and negative thermal anomalies in the Molasse Basin. We assume conductive heat transport and compare calculated temperatures to measured values and to other published 3D models. Areas where predicted and observed temperatures match closely are interpreted to be dominated by conductive heat transport. For areas, where a poor fit between modelled and observed temperatures has been obtained, we discuss possible reasons of this misfit. In particular, an additional contribution by fluid flow to the heat transport is likely. We conclude that the thermal field is controlled by conduction in the lithospheric mantle and the crystalline crust. Furthermore, we show that the positive and negative thermal anomalies in the Molasse Basin are partly triggered by the structural configuration of the crystalline crust. In particular, the domains of the Tauern Body and the upper part of the Alpine crust on the one hand and the insulating Molasse Basin sediments on the other hand control the shallow thermal field of the Molasse Basin area in response to their contrasting thermal properties. Our results demonstrate that the foreland basin and the adjoining Alps have to be regarded as an interdependent system that needs to be considered adequately if the present-day $3 \mathrm{D}$ thermal field of that area is assessed.
\end{abstract}

Keywords: Molasse Basin, 3D thermal field, Thermal anomaly, Alps, Upper Jurassic

\section{Background}

\section{The North Alpine Foreland Basin}

The North Alpine Foreland Basin, also known as the European Molasse Basin, is a Tertiary foreland basin situated in the northern front of the European Alps (Fig. 1). The formation of the basin is closely connected to the closure of the Tethys Ocean and the Alpine orogeny since the Cretaceous (Schmid et al. 2008). With the stacking of the Alpine mountains in the course of the collision process significant loads have been imposed onto the colliding tectonic plates, leading to a flexural response of the crystalline crust underlying the Alps and the creation of the wedge-shaped Molasse Basin. Today this foredeep is filled with clastic sediments, the Molasse, originating from

(C) 2015 Przybycin et al. This article is distributed under the terms of the Creative Commons Attribution 4.0 International License (http://creativecommons.org/licenses/by/4.0/), which permits unrestricted use, distribution, and reproduction in any medium, provided you give appropriate credit to the original author(s) and the source, provide a link to the Creative Commons license, and indicate if changes were made. 


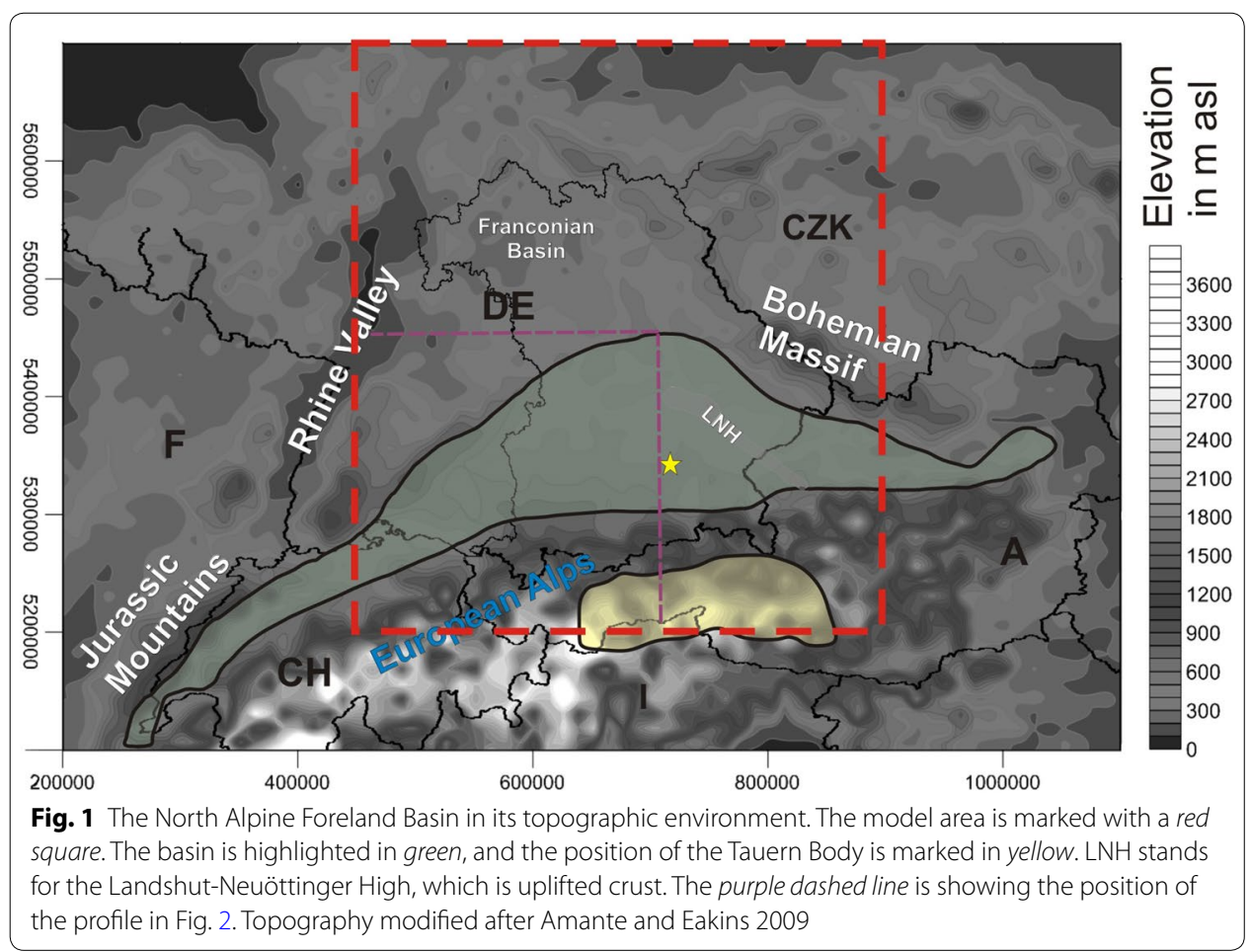

erosional processes of the Alps (Roeder and Bachmann 1996). These Tertiary sediments are underlain by a Mesozoic sedimentary succession, including the Upper Jurassic aquifer (Malm) (Birner et al. 2011, 2012), which is today intensively used for geothermal energy production, and a crystalline crust of Paleozoic age (Lemcke 1973; Freudenberger and Schwerd 1996; Schmid et al. 2004a, b; Berge and Veal 2005; Schmid et al. 2008). Roughly said, the adjoining Alps consist of nappes stacked due to the collision and subduction processes in the Mediterranean area during Late Cretaceous to Cenozoic times (Schmid et al. 2004a, b; Handy and Rosenberg 2011). These calcareous nappes are punctuated by crystalline domes uplifted during the long time of tectonic activity, which are today outcropping in tectonic windows in the Alps (Tauern, Engadine and Rechnitz windows, Brückl 2011). Caused by tectonic processes related to the continental collision of Europe and Africa, large-scale fault zones occur in the Molasse Basin and the Alps (Schmid et al. 2004a, b). Such fault zones might have a significant local influence on the present-day thermal field since they may act as pathways for fluid flow and could enhance fluid flow related cooling. For a more detailed description of the structural and tectonic architecture of the Alpine collision zone and the Molasse Basin, we refer to Freudenberger and Schwerd (1996), Schmid et al. (2004a, b), Thomas et al. (2006) and Brückl et al. (2010).

\section{Geothermal field of the Molasse Basin}

The North Alpine Foreland Basin and its underlying sediments have been explored for hydrocarbons since the beginning of the 20th century (Sachsenhofer et al. 2006) and subsequently for geothermal energy since the 1960s (Bachmann et al. 1982). While the relevance of geothermal energy production in the European Molasse Basin has increased 
steadily during the past decades (Roeder and Bachmann 1996; Kempf et al. 1999; Berge and Veal 2005; Jodocy and Stober 2009; Pamer and Diepolder 2010; Böhm et al. 2011; Reischenbacher and Sachsenhofer 2011; Birner et al. 2012; Cacace et al. 2013; GeoMol Team 2015) its significance as a provider of fossil fuels has decreased (Pasternak 2015). Today, the Tertiary aquifers in the European Molasse Basin and the underlying Mesozoic units are intensively used for shallow as well as for deep geothermal energy production and contribute to the provision of so-called "green energy". Unfortunately, the production rates and the potential extraction temperature may vary significantly regionally as well as locally even in a single hydraulically conductive layer, phenomena that are poorly understood. Such a case occurs in the south-eastern proximity of the city of Munich (Germany) in the Molasse Basin, where the temperature of the geothermal fluid decreases rapidly laterally within a few kilometres by 40-50 K (StMWIT 2010) in the Malm aquifer. Even though huge amount of data exist for the European Molasse Basin obtained from different studies, the described strong local temperature decrease cannot be explained based on the present-day knowledge. The most decisive factors are the irregular data coverage in the basin area and the possibly deep-rooted and threedimensional character of the causative processes. In areas of the Molasse Basin, where increased groundwater temperatures have been found in the past, exploration effort has been increased yielding more data. In contrast, where the extracted temperatures have been disappointing, exploration efforts have been reduced resulting in a lack of further data. Even where the amount of data is large, the lateral variations in temperatures are not always understood. Significant processes of heat transport can act on a basin-wide scale and can be influenced by neighbouring and local structures, such as the Alpine mountain chain and large fault zones, and thus have to be regarded in 3D. Until today, several studies have been conducted using different approaches addressing the temperature distribution in the Molasse Basin (numerical modelling approach: Rühaak et al. 2010, interpolation approach: Agemar et al. 2014a, b) or the European Alps (Vosteen 2003; Ebbing 2004; Ebbing et al. 2006). However, studies regarding both the basin and the mountain chain as an interdependent system are either two-dimensional, of local scale, or have an insufficient resolution of geological structures and tectonic elements to reproduce the local to regional temperature variations. Accordingly, it remains open which heat transport processes are acting on a regional scale.

\section{Modelling approach}

To address the problem of vertical resolution and horizontal coverage, we use the databased lithospheric-scale 3D structural model of the European Molasse Basin of Przybycin et al. (2015) to calculate the 3D conductive thermal field. The model covers the whole German part of the Molasse Basin, as well as the Northern Calcareous Alps, the Central Eastern Alps and the Tauern Body to the south and the South German Scarpland to the north. This model resolves the basin configuration with a higher resolution than previously published for such regional extent. Moreover, the model integrates all freely available depth and thickness information (wells, seismic lines) as well as faults as interpolation barriers and has been additionally constrained by 3D gravity modelling. With our study we assess whether the measured temperatures at depth in the basin can be reproduced with a purely conductive approach, assuming that the temperature 
distribution over the largest parts of the model area is mostly controlled by the structural setting and the related variations in thermal properties. In consequence, for areas where the temperature field cannot be reproduced assuming purely conductive heat transport, an additional influence of heat transport related to fluid flow on the thermal field is likely, especially when taking into account large fault zones permeable for fluid flow in the basin area.

\section{Earlier studies}

As mentioned, earlier studies have dealt with the temperature field of the Molasse Basin before. Rühaak (2009) and Rühaak et al. (2010) present a temperature distribution calculated for the western Molasse Basin based on a 3D quasi steady-state conductive thermal model. They quote, that the temperature distribution in the upper crystalline crust is dominated by conductive heat transport and indicate that the thermal field in the sediments is controlled by advection and groundwater flow. They further conclude that the strong thermal anomalies in the Molasse Basin may be explained by E-W striking faults intersecting aquifers and being characterized by fault parallel fluid flow. However, the model of Rühaak (2009) and Rühaak et al. (2010) was structurally based only on well information due to the lack of other data and assumed a constant basal heat flow at a fixed depth as lower thermal boundary condition. In contrast, the structural model used here integrates multidisciplinary depth and thickness information (wells, seismic lines, gravity). Moreover, we attempt to consider variations of basal heat flow in response to lithospheric heterogeneity. Instead of using a constant heat flux at a constant (shallow) depth, we use a physically motivated lower thermal boundary condition, in which we assume the thermal Lithosphere-Asthenosphere Boundary to represent the $1300{ }^{\circ} \mathrm{C}$-isotherm, which may vary in depth across the model area. However, in conformance with Rühaak (2009) and Rühaak (2010), heat transport related to fluid flow is not considered in this study. Considering advective and convective heat transport in the calculation would require a much higher horizontal and vertical resolution of the model than the one chosen for this study and thus much more information about the hydrogeological structure and property distribution, which was not accessible for this study. Though, the provided conductive part of the thermal field of the Molasse Basin area may be used as starting point for further coupled fluid and heat transport simulations to understand the origin of the distinct positive and negative thermal anomalies in the basin area.

One other project investigating the deep temperature distribution in the European Molasse Basin is the project GeotIS (Geothermal Information System; Schulz et al. 2009; Agemar et al. 2012, 2014a, b) conducted by the Leibniz Institute for Applied Geophysics (LIAG) in Germany. This internet-based geothermal information system provides information about deep aquifers and geothermal productions sites in geothermally active areas of Germany. The data cover parts of the North German Basin, the Upper Rhine Valley and the South German Molasse Basin including more than 30,000 wells from industry and academia. GeotIS serves as a fundament for feasibility studies conducted by the geothermal industry (Schulz et al. 2009) by providing geoscientific base information in terms of depth maps of geothermally relevant aquifers, hydraulicand temperature data and is updated constantly with newly acquired information. 
Based on measured data a 3D temperature model of Germany has been published for the European Molasse Basin by Agemar et al. (2014b), in which single temperature measurements have been interpolated in three dimensions. Using bottom hole temperature measurements and/or temperature data from drillstem tests these interpolations were done using $3 \mathrm{D}$ kriging interpolation. From the resulting model temperature information may be extracted for different depths down to $5000 \mathrm{~m}$ below sea level, whereby the reliability and spatial coverage of the measurements decrease with depth due to the decreasing data density and increasing measuring uncertainties. Even though this model does not consider heterogeneities in subsurface properties or heat transport processes, it provides the most actual up-to-date map of the present-day deep thermal configuration of the basin. However, the 3D interpolation results may be improved in future by taking into account different quality classes of temperature measurements, an approach tested by Rühaak (2015) who used the temperature database of the Leibniz Institute of Applied Geophysics (LIAG) to assess the temperature distribution in the German Molasse Basin with weighted 3D temperature interpolations.

Since original data from temperature measurements performed by the oil and gas industry are partly confidential and thus not accessible, the thermal model of GeotIS was used as the target temperature configuration to compare modelled temperatures for the shallow part of the basin down to a depth of $4000 \mathrm{~m}$ bsl. Furthermore, we compared our calculated temperatures to published values of temperature measurements from 24 geothermal production sites in Southern Germany (Table 1).

\section{The lithospheric-scale 3D structural model}

The structural model our calculations are based on is the lithospheric-scale 3D structural model of Przybycin et al. (2015, Fig. 2), which is based on 2D maps (Freudenberger and Schwerd 1996; StMVIT 2010), on the 3D structural models of Baden-Württemberg (Rupf and Nitsch 2008) and Munich (Schulz et al. 2012), and several deep seismic profiles [TRANSALP (e.g. Gebrande and the TRANSALP working group 2001), CELEBRATION (e.g. Hrubcová et al. 2002), ALP2002 (e.g. Brückl et al. 2010), ALPASS (e.g. Mitterbauer et al. 2011)]. Thus, the model resolves six lithostratigraphic units in the sedimentary part of the basin [the Nördlinger Ries Impact structure, the Folded Molasse as well as the Foreland Molasse Sediments, the Cretaceous, the Upper Jurassic (Malm), the Middle and Lower Jurassic and Triassic sediments summarized in one unit called the PreMalm Sediments] and two units in the Alps (the Alpine Body and the Tauern Body). Below this sedimentary part, the structural model consists of a two-parted crust (upper and lower crystalline crust) bending towards the south and a lithospheric mantle. The bending of the crystalline crust, and with it the wedge shape of the basin, was caused by the continental collision and the rise of Alps. This wedge shape of the basin causes a non-uniform distribution of the thicknesses of the Tertiary Molasse Sediments (Figs. 3, 4). Accordingly, the sediments of the Foreland Molasse (Fig. 3c) increase in their thickness from $0 \mathrm{~m}$ in the north to up to $5 \mathrm{~km}$ in the south. The Foreland Molasse Sediments are separated from the Alps by the Folded Molasse Sediments (Fig. 3b), which are strongly internally deformed and party overridden by the Alps. These sediments show apparent thicknesses of up to $7 \mathrm{~km}$ in a thin belt in front of the Alps. 


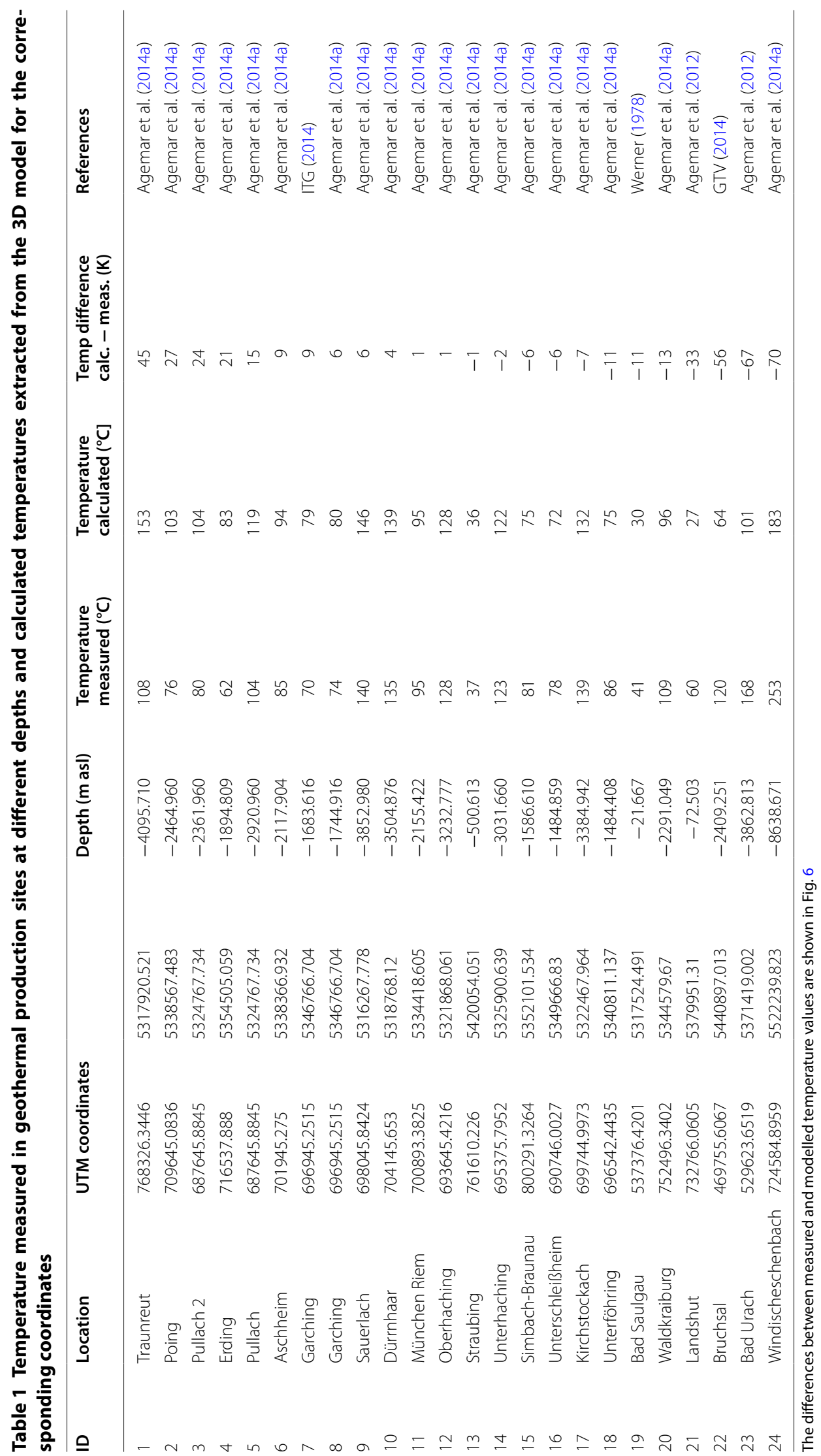




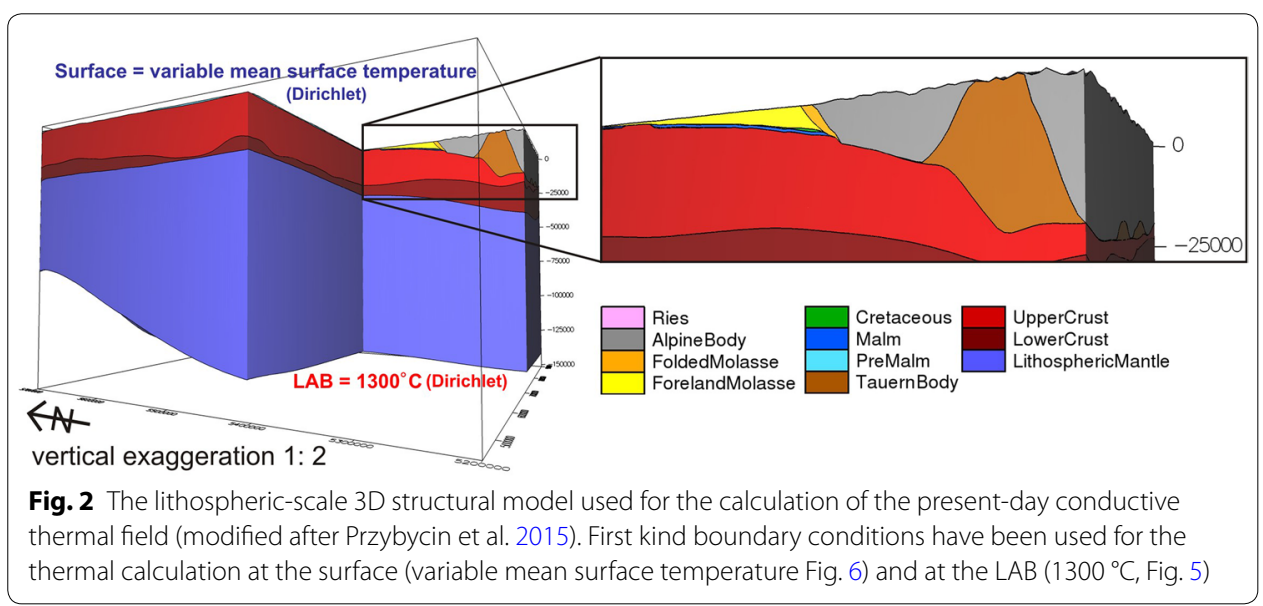

Underlying the Molasse Sediments, the Cretaceous (Fig. 3d) is only preserved in a restricted domain with thicknesses of up to $850 \mathrm{~m}$ with small outcropping areas of low thickness at the western rim of the Bohemian Massif. Below the Cretaceous, the Upper Jurassic (Malm, Fig. 3e) shows reduced thicknesses in the outcropping domain in the north which increase southwards to up to $650 \mathrm{~m}$ directly in front of the orogen. The Malm is partly eroded above the uplifted crust of the Landshut-Neuöttinger High (LNH). Apart from the Malm, all Jurassic and Triassic sediments have been summarized in one unit, the PreMalm Mesozoic Sediments (Fig. 3f), which show highest thickness values (up to $1500 \mathrm{~m}$ ) in the Franconian Basin.

At the northern rim of the Molasse Basin, the Nördlinger Ries (Fig. 3a), an impact structure 14.6 Ma in age (Jankowski 1977) with a diameter of $\sim 23 \mathrm{~km}$, cuts through all units down to the crust with a maximum thickness of up to $600 \mathrm{~m}$.

Since the structural model of Przybycin et al. (2015) focuses on the Molasse Basin and considers the Alps only as first-order structure, all deformed sedimentary units in the Alpine area have been summarized into one model unit, the Alpine Body (Fig. 4a), with average thermal properties (Table 2). This Alpine Body shows thicknesses of up to $30 \mathrm{~km}$ at the southern model boundary and is disrupted by the Tauern Body (Fig. 4b), which in turn shows thickness values of up to $30 \mathrm{~km}$ as well. The Tauern Body comprises all nonsedimentary units occurring within this crystalline core. We admit that summarizing all lithological units occurring in the Alpine area into two units, the Alpine Body and the Tauern Body, is a strong simplification of the geological situation of the Alps. This was done because of two reasons: The first reason is the general goal of this study. With this study we wanted to investigate the first-order interdependence of the Alpine area with the Molasse Basin related to the long-wavelength thermal field. Resolving the geological structure in the Alps better would surely introduce local thermal effects in the thermal field in the Alps. However, the long wavelength thermal field and the temperature distribution in the Molasse Basin would not be significantly changed. The second reason for the strong simplification is the non- uniform distribution of geological information in the Alps, especially for deeper parts, which renders a three-dimensional representation of the Alpine area with high resolution mostly challenging. To assess the influence of this simplification the different lithologies considered in the units Alpine Body and Tauern 


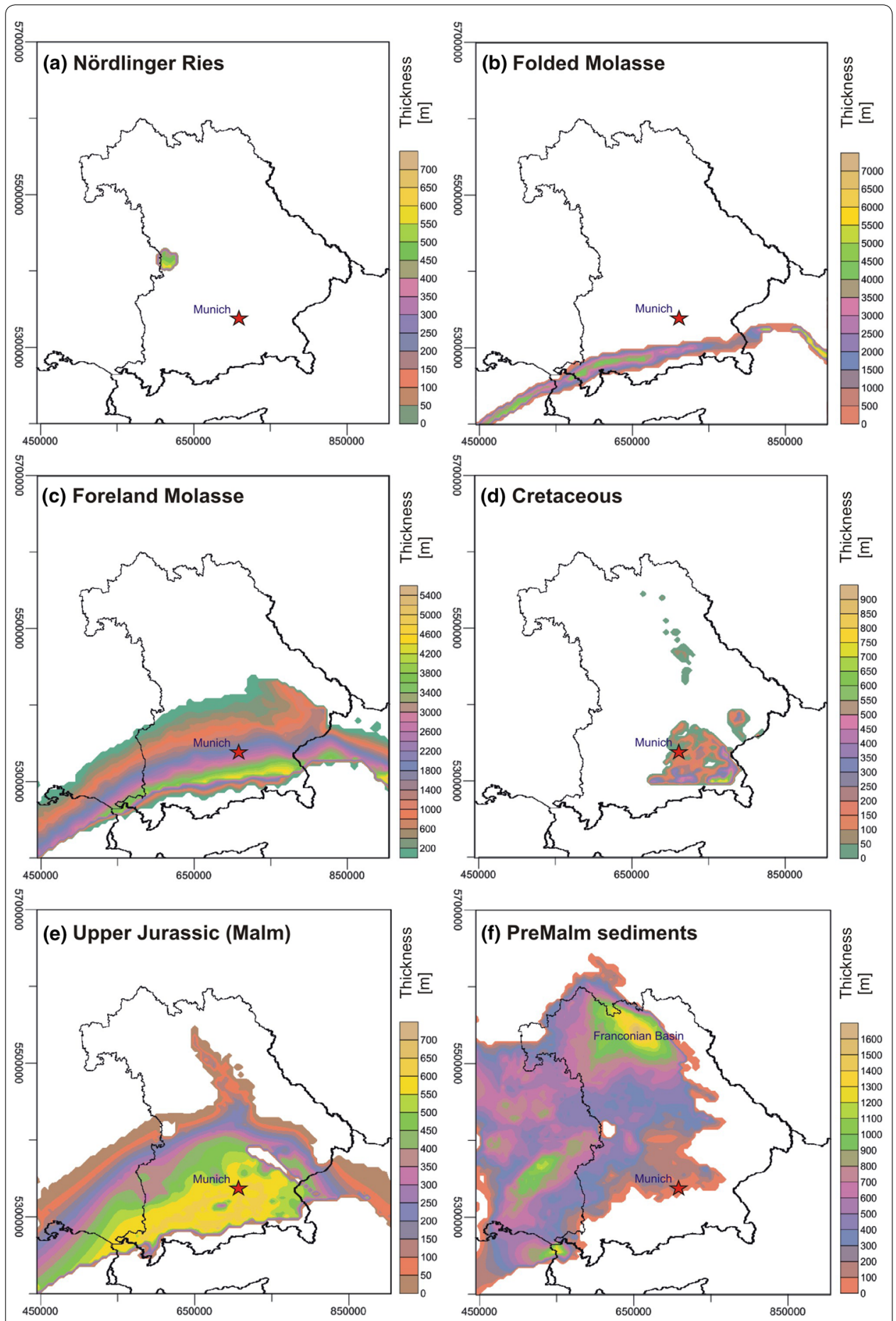

Fig. 3 Thickness maps a-f of the sedimentary units resolved in the 3D structural model (modified after Przybycin et al. 2015)

Body are summarized in Table 2. Moreover a range of values for these thermal properties was tested.

The base of the crystalline crust in the model has been defined by integrating the Moho depth of Grad et al. (2009). There resulting crystalline crustal layer is split into 


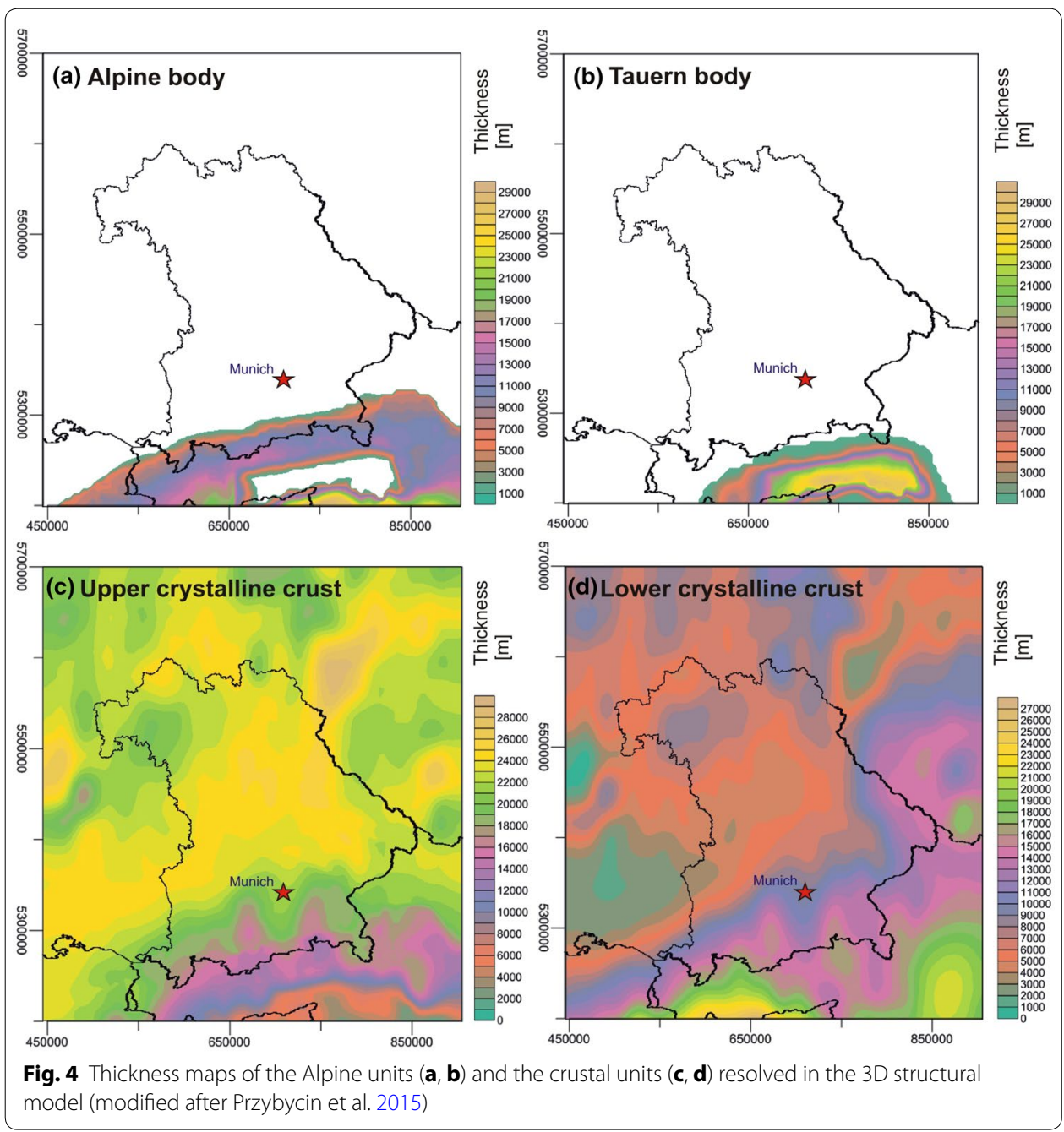

an upper and a lower part. The depth of the upper crust-lower crust interface has been calculated using isostatic principles as well as 3D gravity modelling and is partly constrained by a deep seismic profile (Przybycin et al. 2015). Accordingly, the two crystalline crustal layers (Fig. 4c, d) show opposed thickness distributions with a thick lower crystalline crust below the Alps, an intermediately thick lower crystalline crust below the basin and the Bohemian Massif and a thin lower crystalline crust in the north and west of the model area (vice versa for the upper crystalline crust). Gravity modelling and seismic data indicate that the seismic velocities and the densities of the upper crust correspond to an acidic (granitic to granodioritic) composition whereas the lower crust is of mafic composition (gabbro). Furthermore, a seismologically derived LithosphereAsthenosphere Boundary (Fig. 5) has been implemented integrating results of Tesauro (2009), Geissler et al. (2010), Karousova et al. (2013), Seiberlich et al. (2013) and Bianchi et al. (2014). The LAB is deepest (up to $150 \mathrm{~km} \mathrm{bsl}$ ) below the Alps, moderately deep 


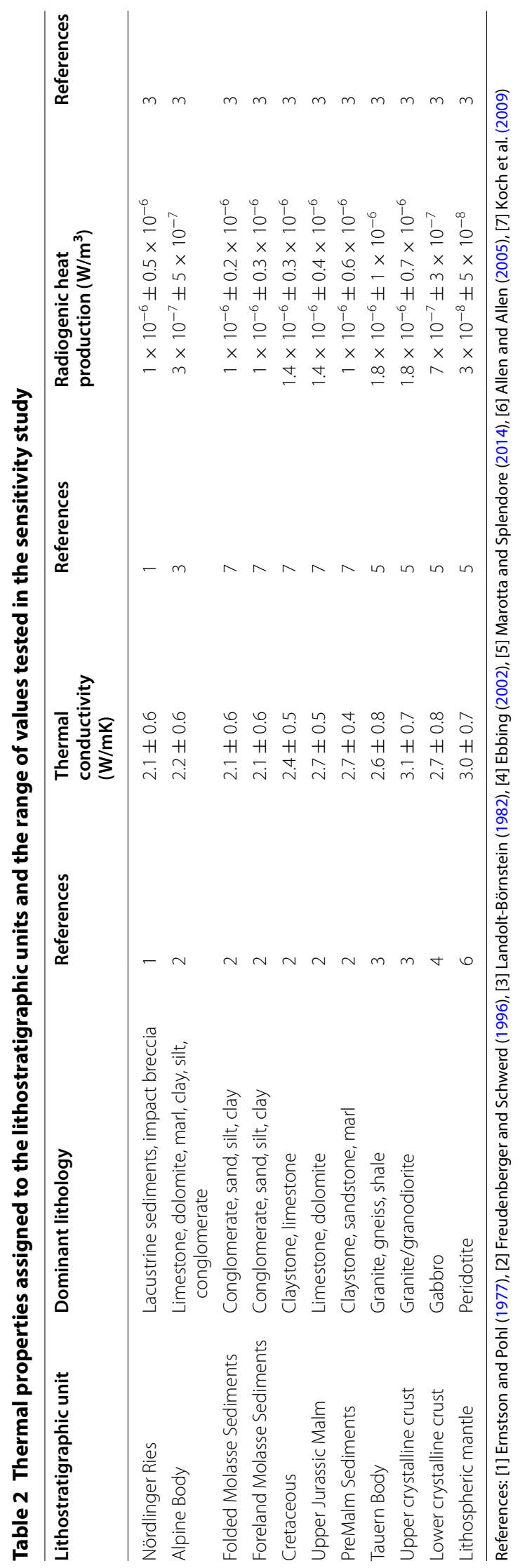




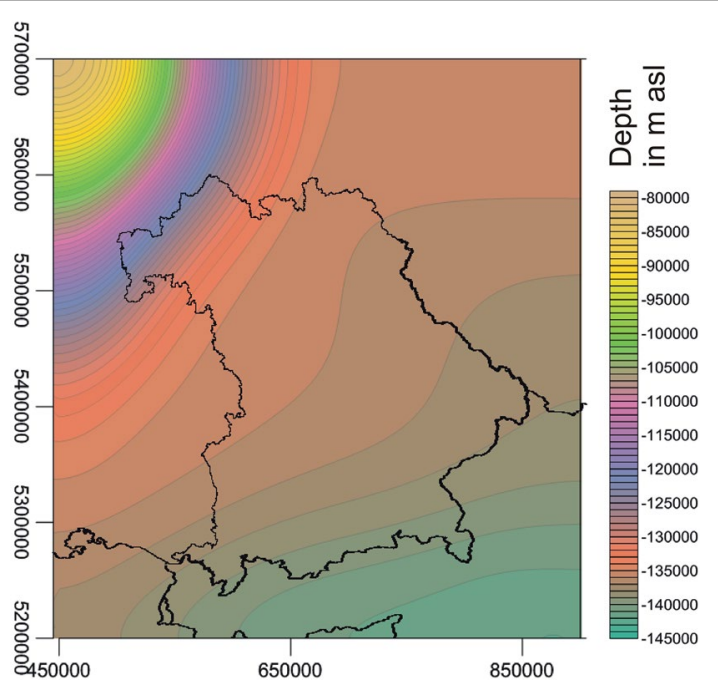

Fig. 5 Depth of the Lithosphere-Asthenosphere Boundary used for this study (modified after Przybycin et al. 2015) as the lower thermal boundary for the calculation of the 3D thermal field, to which an isothermal temperature of $1300^{\circ} \mathrm{C}$ is assigned

( $130 \mathrm{~km}$ bsl) below the Bohemian Massif and the Molasse Basin and rises below the Eifel plume $(\sim 80 \mathrm{~km} \mathrm{bsl})$ in the northwest.

For our calculation of the thermal field we have adopted this structural model as described, to calculate the regional impact of the different lithostratigraphic units as first-order structures on the temperature field.

\section{Method}

Conductive heat transport is based on the theory of energy transfer (in this case thermal energy) by diffusion due to a temperature gradient within a body with the goal to reach thermodynamic equilibration. The base of the domain influenced by conductive heat transport is represented by the thermal Lithosphere-Asthenosphere Boundary (LAB), which is defined as the $1300{ }^{\circ} \mathrm{C}$-isotherm. Depending on the depth of the LAB, an average geothermal gradient evolves in the lithosphere along which heat is transported to the surface. In areas where the LAB is shallower than average, a steeper thermal gradient evolves, and vice versa. In areas with steeper geothermal gradients heat is transported more efficiently towards the surface, thus causing positive thermal anomalies in shallow sedimentary successions, which are targets for geothermal projects. Additionally, the geothermal gradient is influenced by material specific parameters, as the thermal conductivity and the radiogenic heat production.

To calculate the present-day thermal field of the Molasse Basin area the conductive heat equation for steady-state conditions (Eq. 1) has been solved using a 3D finite element method (Scheck and Bayer 1999; Scheck et al. 2003) with $\lambda$ as the thermal conductivity, $T$ as the temperature and $S$ as the radiogenic heat production.

$$
0=\operatorname{div}(\lambda \operatorname{grad} T)+S
$$


Thermal conductivity is defined as the heat flow across a specific cross-section and along a specific distance for a defined temperature decrease in a defined time (Clauser 2011a). In a material with higher thermal conductivity (e.g. crustal material) heat is transported more efficiently than in a material with lower thermal conductivity (e.g. sediments). Thus, in areas where crustal material lies shallower, but is covered by insulating sediments, higher temperatures can be expected at shallower depths than in areas with deeper lying crustal material. Vice versa, where crustal material is exposed, heat can escape the system more efficiently than in areas where crustal material is covered by sediments. Hence, lower temperatures can be expected in areas where crustal material is outcropping than in areas where crustal material is covered. Even though anisotropic conditions are not deniable even within single sedimentary layers of the Molasse Basin, we have considered all units of the model as isotropic in our calculations due to a lack of data and admit that this is a limitation of our model.

The radiogenic heat production represents the amount of thermal energy set free by the decay of radiogenic isotopes in a defined volume in a defined timespan (Clauser 2011b) and thus has to be considered as an additional heat source in the calculation. Since more additional heat is generated in the silicic upper crystalline crust because of radioactive decay than in mafic lower crystalline crust or sediments, more additional heat is introduced into the system by crystalline material of acidic composition than by mafic material and sediments. This leads to higher temperatures in areas with thicker acidic upper crystalline crust than in areas where the upper crust is thin.

Like the thermal conductivity, the radiogenic heat production is a specific material characteristic depending on the material composition and can vary significantly for different lithologies.

For the calculation of the thermal field of the basin, all lithostratigraphic units of the model have been characterized with average values for the thermal conductivity and the radiogenic heat production according to their lithological composition (Table 2). Where available, measured values of the respective properties have been favoured, like for the sediments (Ernstson and Pohl 1977; Landolt-Börnstein 1982; Freudenberger and Schwerd 1996; Ebbing 2002; Allen and Allen 2005; Koch et al. 2009; Marotta and Splendore 2014). For deeper parts, where no measured values were available, average published values have been chosen for the assumed lithology.

Furthermore, the calculation of the thermal field not only depends on the heat conduction and the radiogenic heat production, but also on the chosen thermal boundary conditions. For our calculation we used a 1st kind upper boundary condition (Dirichlet) by assigning a variable mean surface temperature to the top surface of the model (topography) based on averaged measured surface temperature values between 1961 and 1990 (DWD 2013; InMeteo 2013; HISTALP 2013, Fig. 6). Besides, a 1st kind lower boundary condition (Dirichlet) was assigned to the thermal LAB with a constant value of $1300{ }^{\circ} \mathrm{C}$ (Fig. 5).

To evaluate the influence of the assigned values for thermal conductivity and radiogenic heat production of each lithostratigraphic layer on the resulting thermal field, a sensitivity study has been carried out. Thus, a reasonable range of plausible values has been tested. 


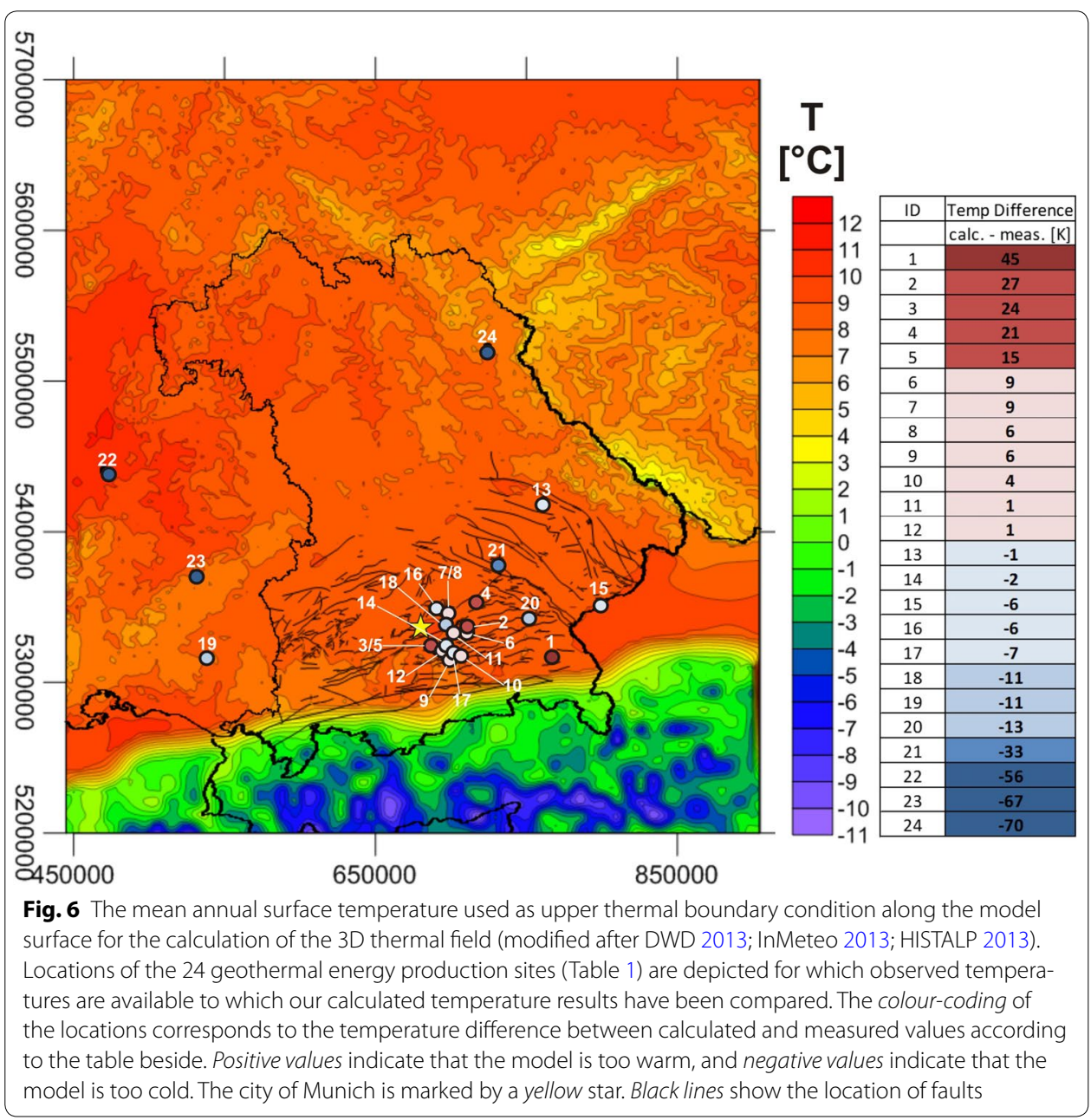

\section{Results}

\section{The present-day 3D thermal field}

In the calculated 3D temperature distribution (Fig. 7), the temperature increases nonuniformly with depth over the whole model area and several general thermal effects are evident (Figs. 7, 8, 9).

The $\mathrm{LAB}$ as the $1300{ }^{\circ} \mathrm{C}$ isotherm lies shallower in the north and northwest than in the south of the model with a smooth transition in between (Fig. 7). Accordingly, the geothermal gradient is much steeper in areas of a shallower LAB (northern and northwestern part of the model area towards the Eifel plume) than in areas of a deep LAB (Alps). This effect results in vertically closer-spaced isotherms in the north than in the south (Fig. 7). Furthermore, the isotherms in the lithospheric mantle are bent upwards in the northwestern corner and flat in the northern and northeastern model part, whereas they are bent downwards in the central part of the model below the basin. In the area of the Alps, where the modelled LAB is deepest in our model, the isotherms are curved upwards in the mantle.

In most parts of the model the isotherms are flat in the crystalline crust, illustrating a continuous decrease of temperature towards the surface. In contrast, the isotherms are bent upwards in the crystalline crust below the basin and even stronger below the Alps. 


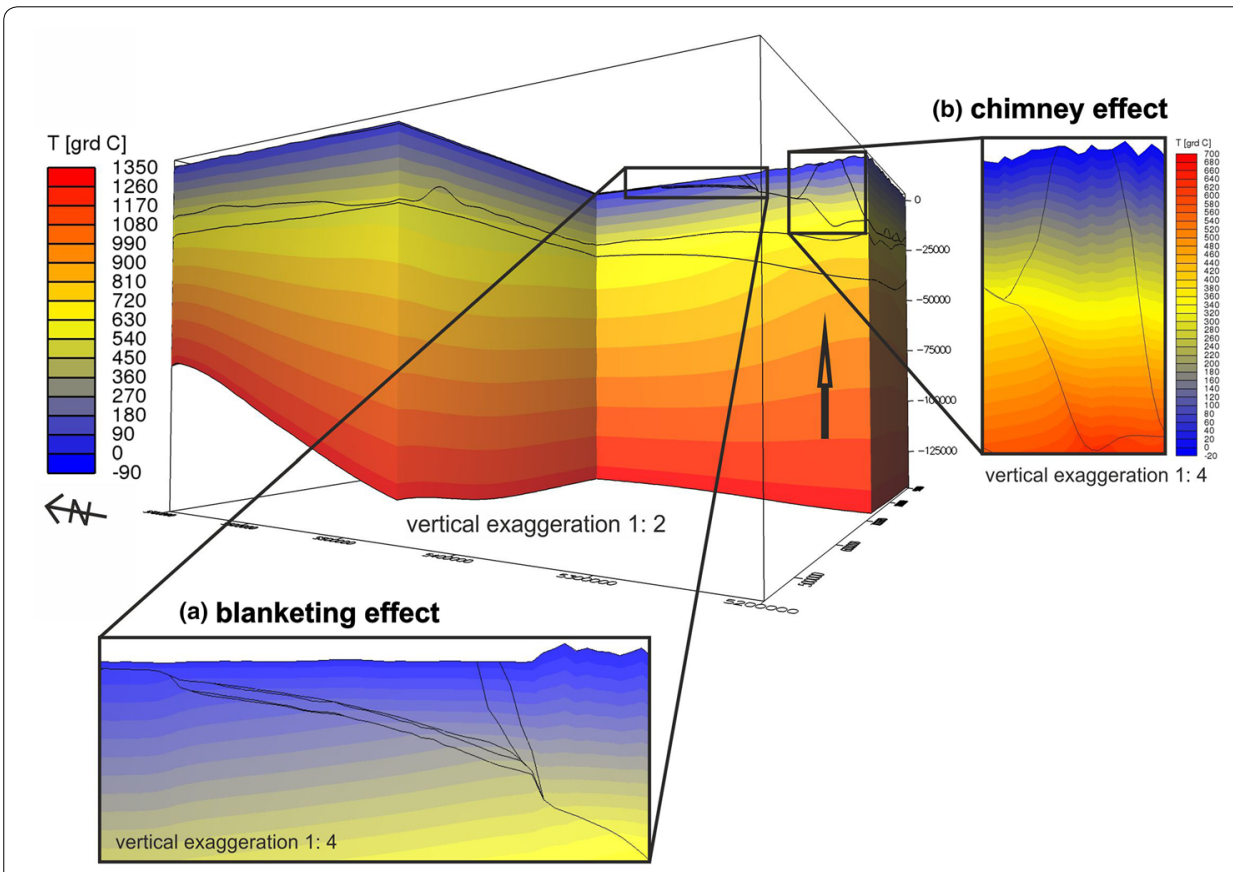

Fig. 7 The resulting present-day lithospheric-scale 3D conductive thermal field of the Molasse Basin area. Subpanels $a$ and $b$ zoom into areas of specific thermal effects with $a$ thermal blanketing effect and $b$ chimney effect (shown with higher temperature resolution, scale shown at zoom-in $b$ )

At the transition between the crystalline crust and the sediments, the shape of the isotherms changes in the domain of the Tauern Body. There, the upward-curved isotherms in the mantle and the crystalline crust flatten and even turn into a downward-curved shape when entering the Tauern Body (Fig. 7a). The isotherms flatten again when entering the sediments of the Alpine Body. Accordingly, cooler temperatures are predicted in the Tauern Body than in the Alpine Body at shallow depth.

The upwards curved isotherms in the mantle and crust flatten when entering the Mesozoic sediments below the Molasse Basin (Fig. 7b). This results in higher temperatures in the Mesozoic sediments under and in the Molasse Basin than in the northern parts of the model, where no insulating sediments are covering the crystalline crust.

At all depths within the sedimentary part (Figs. 8a-f, 9a, b) a colder part in the north and a warmer part in the south are predicted with distinct short-wavelength temperature variations. These anomalies are in close correlation with topographic highs and can be traced in the temperature distribution at all depths in the sedimentary part.

To illustrate how the calculated temperatures change non-uniformly with depth, Figs. 8 and 9 presents different temperature-depths maps.

At a depth of $1000 \mathrm{~m}$ bsl (Fig. 8a) the colder part in the north shows temperatures between 25 and $50{ }^{\circ} \mathrm{C}$, while the warmer part in the south shows temperatures of up to $105{ }^{\circ} \mathrm{C}$. The outer frame of the Molasse Basin and the outcropping Mesozoic sediments can be clearly recognized in the temperature distribution. Within the basin, temperatures between 50 and $70{ }^{\circ} \mathrm{C}$ are predicted with a general trend of southwards increasing temperatures. A minor negative temperature anomaly with a difference in temperature 


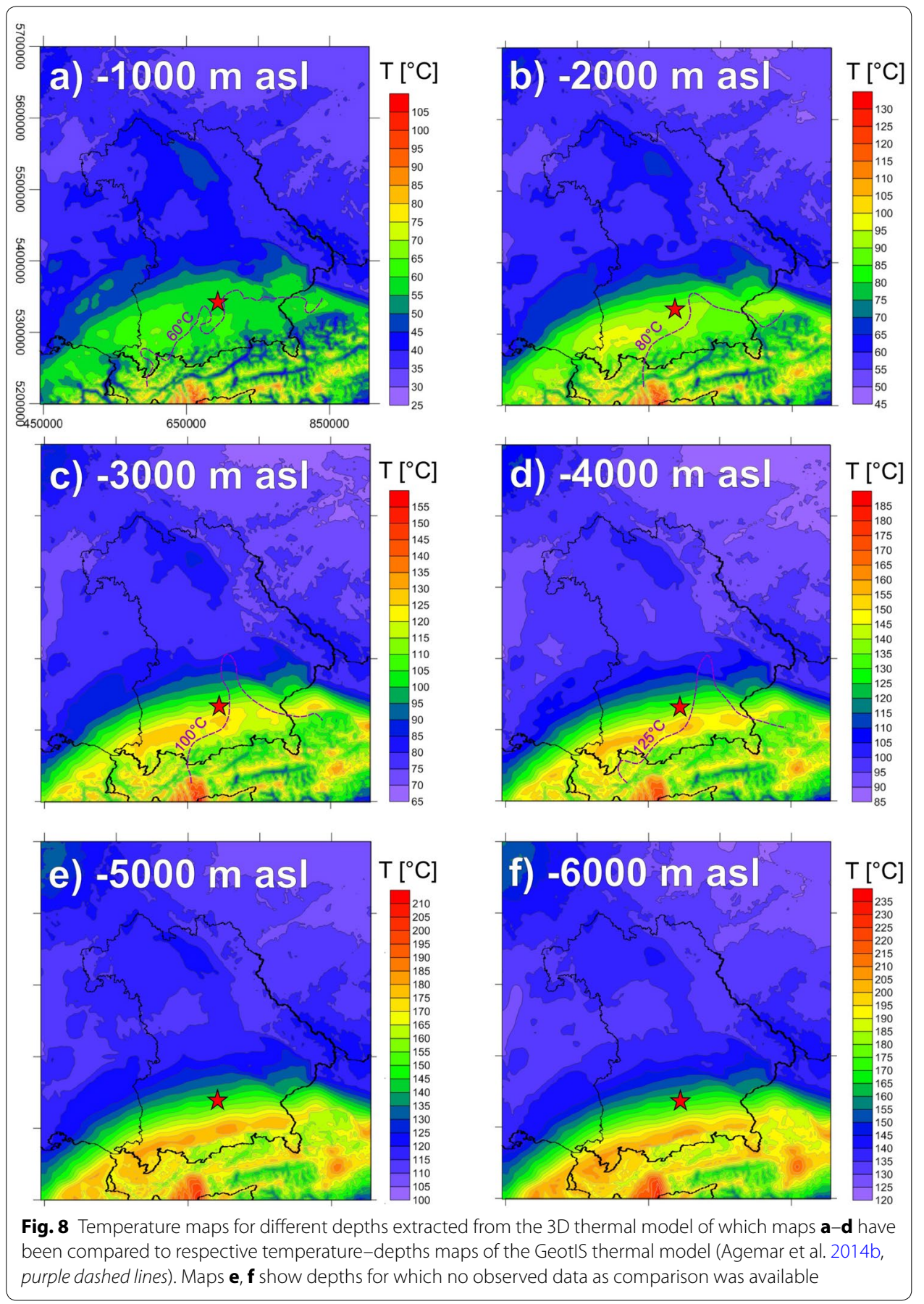

of 5-10 K is predicted south of Munich (city marked with a red star) and a short-wavelength positive anomaly is modelled in the southwestern corner of Bavaria.

The binary division of the thermal signature of the basin is also present in the temperature distribution at $2000 \mathrm{~m}$ bsl (Fig. 8b), where calculated temperatures vary between 60 and $96{ }^{\circ} \mathrm{C}$. Likewise, both the colder northern part of the model as well as the Alpine area are still distinct with up to 60 and $130{ }^{\circ} \mathrm{C}$, respectively. A positive thermal anomaly at $2000 \mathrm{~m}$ bsl depth is predicted in the western part of the Molasse Basin with 


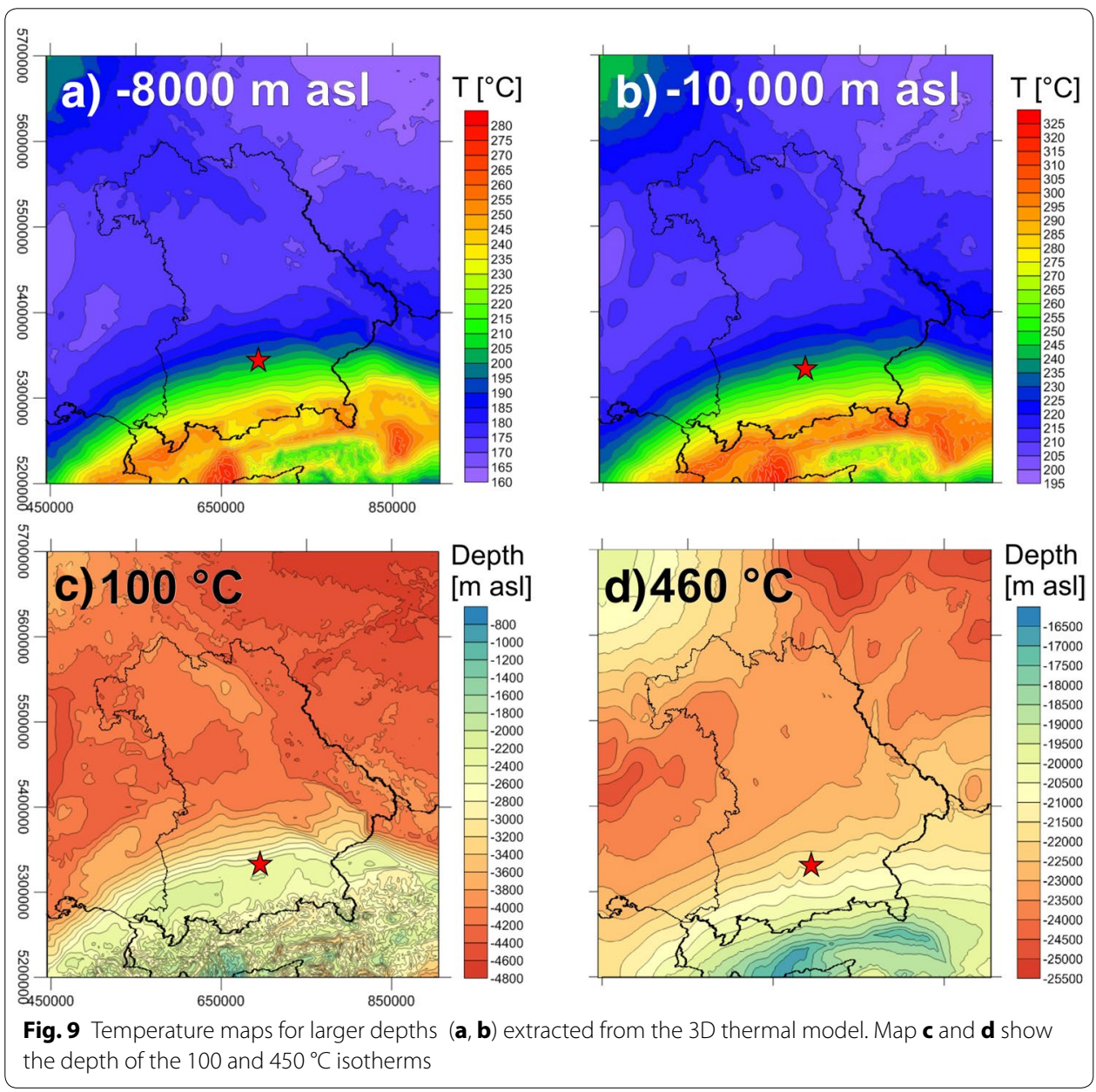

temperatures of up to $95{ }^{\circ} \mathrm{C}$. A second smaller and weaker positive thermal anomaly occurs in the eastern part of the basin in Austria. Between the hotter domains a colder area is predicted by the model.

At a depth of $3000 \mathrm{~m}$ bsl (Fig. 8c) temperatures between 130 and $100{ }^{\circ} \mathrm{C}$ are calculated for the basin area. The temperatures in the Alpine area increase to up to $155{ }^{\circ} \mathrm{C}$, while the northern part of the model area shows temperatures of up to $90{ }^{\circ} \mathrm{C}$ with slightly warmer temperatures in the northwestern corner of the model area towards the Eifel plume.Within the basin, the positive temperature anomaly in the western part attains up to $125{ }^{\circ} \mathrm{C}$. Likewise, the thermal anomaly in the Austrian part increases to $125^{\circ} \mathrm{C}$. Furthermore, a third positive temperature anomaly is visible in the south of the city of Munich with temperatures comparable to the ones of the thermal anomaly in the west of the basin. Between these positive thermal anomalies, an area of colder temperatures is evident southeast of Munich with a temperature difference of up to $20 \mathrm{~K}$ with respect to the neighbouring positive thermal anomalies.

At $4000 \mathrm{~m}$ depth bsl (Fig. 8d) the temperature predicted in the basin ranges between 115 and $160{ }^{\circ} \mathrm{C}$, while the temperatures in the northern model area reach up to $115^{\circ} \mathrm{C}$. In the Alpine area, modelled temperatures are significantly higher and may reach up to $185^{\circ} \mathrm{C}$. The positive thermal anomaly in the western basin as well as the anomaly in 
the south of Munich increases to up to $160^{\circ} \mathrm{C}$. Furthermore, the smaller positive thermal anomaly in the Austrian part of the Molasse Basin has shifted westwards and shows temperatures of up to $160{ }^{\circ} \mathrm{C}$. The negative thermal anomaly in the east-southeast of Munich in between the two positive thermal anomalies shows a temperature of $\sim 145{ }^{\circ} \mathrm{C}$, which is up to $20 \mathrm{~K}$ colder than the temperature within the positive thermal anomalies.

At the depth of $5000 \mathrm{~m}$ bsl (Fig. 8e), the temperatures increase to up to $125{ }^{\circ} \mathrm{C}$ in the northern model part and to $210{ }^{\circ} \mathrm{C}$ in the Alpine area. For the basin area temperatures between 130 and $180^{\circ} \mathrm{C}$ are predicted with some local anomalies of higher temperature. The temperatures characterizing these positive thermal anomalies in the basin increase to up to $185^{\circ} \mathrm{C}$, while the anomaly south of Munich and the one on the eastern border of the German Molasse Basin connect to form a narrow high-temperature bridge. The negative thermal anomaly in the southeast of Munich is far less pronounced than at shallow levels.

At $6000 \mathrm{~m}$ bsl (Fig. 8f) the temperatures in the northern model part and towards the Eifel plume increase to $150{ }^{\circ} \mathrm{C}$. In the Alpine area temperatures of up to $235^{\circ} \mathrm{C}$ are predicted.

The frame of the Molasse Basin can still be recognized clearly in the temperature distribution even at this depth. The basin shows temperatures between 150 and $210{ }^{\circ} \mathrm{C}$. The individual positive thermal anomalies distinct at shallower depths form a realm of higher temperatures at this level (up to $210^{\circ} \mathrm{C}$ ) in the south of Munich.

At depths below $6000 \mathrm{~m}$ bsl (Fig. 9a, b), the pattern of temperature distribution is more smooth than at shallower levels though the contour of the Molasse Basin in the temperature distribution is still visible. In the area of the Molasse Basin the temperature distribution shows a continuous increase from north to south towards the Alps.

At all depths a distinct temperature effect of short wavelength is predicted for the Alpine area. In this domain, the strongly varying surface temperature propagates downward causing higher temperatures in topographically high areas in the Alps. However, this effect decreases with depth and is barely visible below $6000 \mathrm{~m}$ bsl. Noticeable are significantly lower temperatures in the Tauern Body than in the Alpine Body at all depths. This effect is more pronounced in the deeper parts: The temperature difference between the Tauern Body and the Alpine Body rises to up to $80 \mathrm{~K}$ at a depth of 10,000 m bsl.

In case a geothermal power plant shall be used not only for heating, but as well for electric power production, a temperature threshold value of $100{ }^{\circ} \mathrm{C}$ should not be undercut as reservoir temperature (Agemar et al. 2012). Looking at the depth of the $100{ }^{\circ} \mathrm{C}$ isotherm predicted by the model (Fig. 9c), again a binary pattern is visible: In the northern part, the depth of the isotherm ranges between 4800 and $3800 \mathrm{~m}$ bsl. At the northern edge of the Molasse Basin the modelled depth of the $100^{\circ} \mathrm{C}$ isotherm decreases from $3800 \mathrm{~m}$ bsl at the edge of the basin to $2200 \mathrm{~m}$ bsl in the central part. Southward, the $100{ }^{\circ} \mathrm{C}$ isotherms lies nearly flat at a depth of $\sim 2100 \mathrm{~m}$ bsl. Below the Alps the isotherm rises to a depth of up to $800 \mathrm{~m}$ bsl (but still with $>3000 \mathrm{~m}$ below topography) with a strongly irregular course. However, the largest depth values of the $100{ }^{\circ} \mathrm{C}$ isotherm in the Alps can be found in the area of the Tauern Body with up to $3200 \mathrm{~m}$ bsl.

Another prominent isotherm is the $460{ }^{\circ} \mathrm{C}$ isotherm, around which, assuming an average increase of pressure with depth, the brittle-ductile transition zone of crystalline crustal material is assumed (Ranalli 1995). Around this temperature, the rheological behaviour of mainly crystalline rocks changes from brittle to ductile and, therefore, the 
depth of this isotherm sets a threshold below which no earthquakes are expected (Dragoni 1993). Thus, the depth of this transition zone in a specific area is strongly affected by the geothermal gradient: the steeper the gradient the shallower the transition zone (and vice versa). According to our calculation the $460{ }^{\circ} \mathrm{C}$ isotherm is at a depth of 16,500 25,500 $\mathrm{m}$ bsl in the Molasse Basin area (Fig. 9d). This isotherm is deepest in the northeastern and western part of the model area with $25,500 \mathrm{~m}$ bsl and intermediate in the central model area with values around 23,000 m bsl. Towards the northwestern corner of the model area, in the direction of the Eifel plume (Seiberlich et al. 2013), the $460{ }^{\circ} \mathrm{C}$ isotherm rises to up to $19,500 \mathrm{~m}$ bsl. From the northern edge of the Molasse Basin to the south the isotherm rises continuously to $20,000 \mathrm{~m}$ bsl depth at the margin of the Alps. Lowest depth values of this isotherm (up to $16,500 \mathrm{~m} \mathrm{bsl}$ ) are predicted for the area of the Alps, whereby the isotherm is deepest within the Tauern Body. Unlike the $100{ }^{\circ} \mathrm{C}$ isotherm, the depth of the $460^{\circ} \mathrm{C}$ isotherm shows no short-wavelength variations.

\section{Sensitivity analysis with respect to thermal properties}

To assess the influence of each model unit and the prescribed thermal properties on the predicted thermal field a sensitivity study was carried out within which different values for each property were assigned to the model layers (Table 2) and the thermal field was calculated. In Figs. 10 and 11 the predicted temperature distributions at a depth of $3000 \mathrm{~m}$ bsl are shown for the highest and the lowest values assigned, respectively, for the model units exerting the strongest influence on the temperature distribution.

\section{Thermal conductivity}

Figure 10a and $\mathrm{b}$ shows the influence of the thermal conductivity of the Alpine Body on the temperature distribution in the Molasse Basin. Assuming a low thermal conductivity of this model unit (Fig. 10a, 1.6 W/mK) temperatures between 115 and $130{ }^{\circ} \mathrm{C}$ are predicted for the basin with three positive thermal anomalies (in the western part, south of Munich and at the eastern Bavarian border) with temperatures of up to $140{ }^{\circ} \mathrm{C}$. Between the latter two positive thermal anomalies an area with average temperatures $\left(125^{\circ} \mathrm{C}\right) \mathrm{can}$ be seen in the southeast of Munich. Assuming a significantly higher thermal conductivity for the Alpine Body (Fig. 10b, $2.8 \mathrm{~W} / \mathrm{mK}$ ), lower temperatures by $10-15 \mathrm{~K}$ are predicted by the model for the positive thermal anomalies with no pronounced cooler area in the southeast of Munich.

When decreasing the thermal conductivity of the Tauern Body to $2.3 \mathrm{~W} / \mathrm{mK}$ (Fig. 10c) higher temperatures in the area of the Tauern Body and the Alpine Body are predicted compared to the original model by $\sim 20 \mathrm{~K}$. The same temperature shift can be seen in the Molasse Basin, for which temperatures of up to $150{ }^{\circ} \mathrm{C}$ are predicted. Assuming a higher thermal conductivity of the Tauern Body (Fig. 10d, $3.5 \mathrm{~W} / \mathrm{mK}$ ) the area of the Tauern Body shows lower temperatures than in the original model by $\sim 10 \mathrm{~K}$. In addition, the positive thermal anomalies in the Molasse Basin decrease in size and no significant negative thermal anomaly in the southeast of Munich can be seen. Thus, removing the contrast in thermal conductivity between the Alpine and the Tauern Body also causes the negative thermal anomaly southeast of Munich to disappear.

Decreasing the thermal conductivity of the upper crystalline crust in the model to $2.4 \mathrm{~W} / \mathrm{mK}$ (Fig. 10e), the temperature increases by $10 \mathrm{~K}$ in average in the northernand 


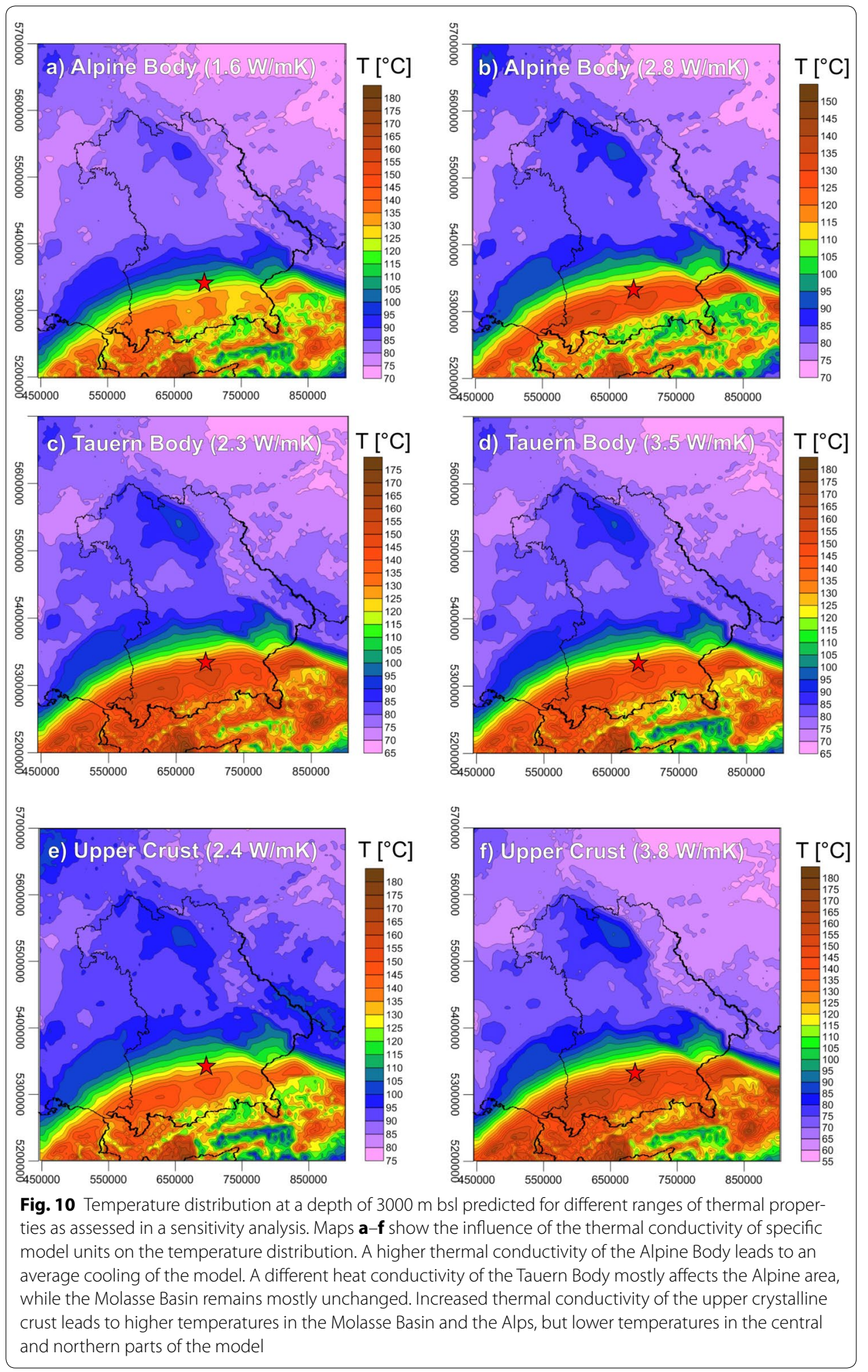


eastern model part where the upper crystalline crust is outcropping with a stronger variation compared to the original model (Fig. 8c). In the basin a temperature change of $\sim 5 \mathrm{~K}$ can be recognized compared to the original model.

Increasing the thermal conductivity of the upper crystalline crust to $3.8 \mathrm{~W} / \mathrm{mK}$ (Fig. 10f) decreases the average temperature in the outcropping areas of the upper crystalline crust in the north and east by $\sim 10 \mathrm{~K}$. The thermal anomalies in the Molasse Basin show no strong influence by the changes in thermal conductivity of the upper crystalline crustal layer compared to the original model.

As visible in Fig. 11a, b, decreasing $(1.9 \mathrm{~W} / \mathrm{mK})$ and increasing $(3.5 \mathrm{~W} / \mathrm{mK})$ the thermal conductivity of the lower crystalline crust have very little influence on the predicted thermal field.

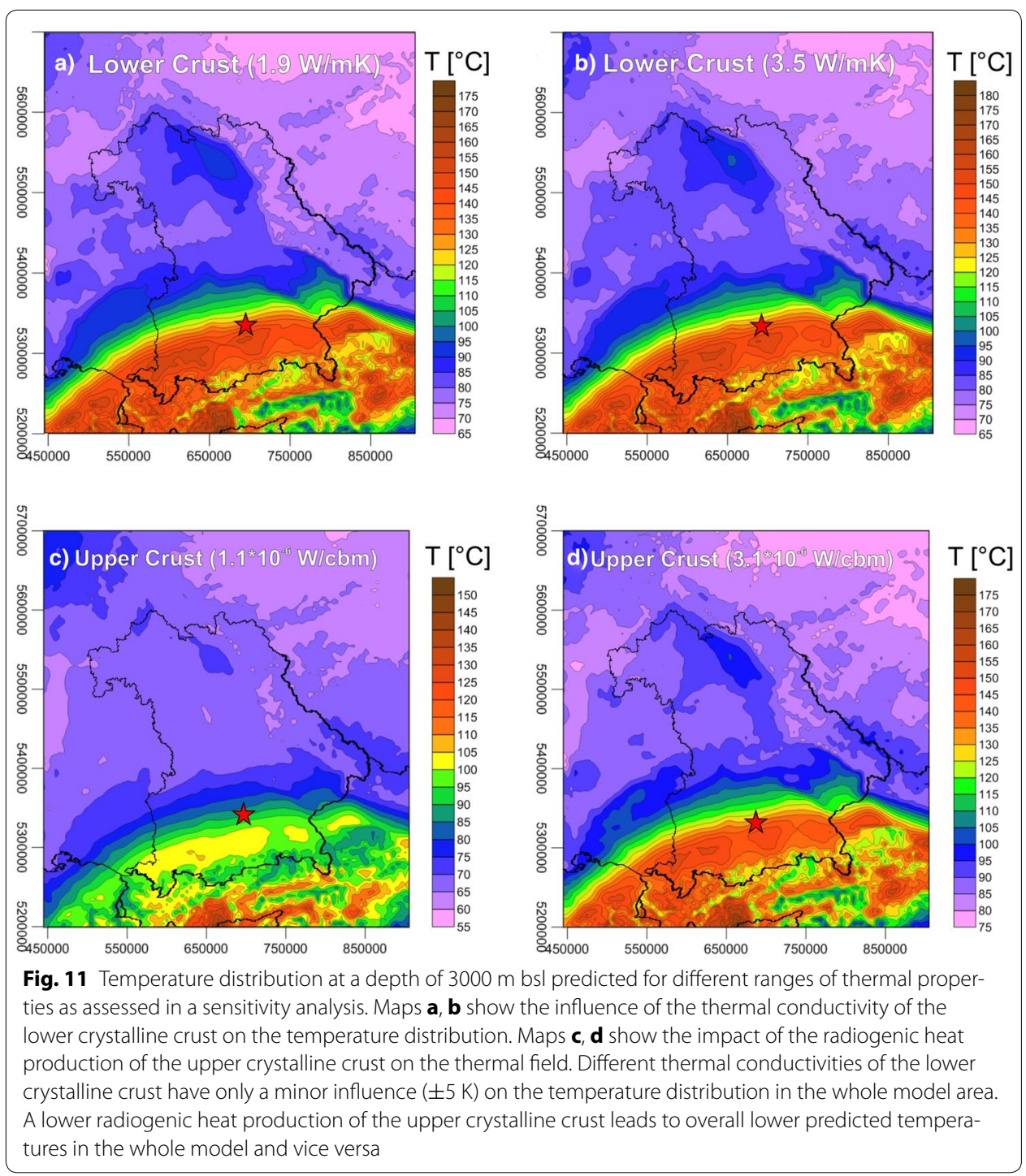




\section{Radiogenic heat production}

Decreasing the radiogenic heat production of the upper crystalline crust to $1.1 \times 10^{-6} \mathrm{~W} / \mathrm{m}^{3}$ (Fig. 11c) leads to an overall cooling of the system compared to the original model, especially in areas with a thick upper crystalline crust as in the northern and western model parts. Those areas show predicted temperatures lower by up to $25 \mathrm{~K}$. The positive thermal anomalies in the Molasse Basin show decreased temperatures by $20 \mathrm{~K}$. Further south in the Alps, where the thickness of the upper crystalline crust is smaller, the temperature difference amounts $\sim-10 \mathrm{~K}$.

Assuming an increased radiogenic heat production of the upper crystalline crust $\left(3.1 \times 10^{-6} \mathrm{~W} / \mathrm{m}^{3}\right.$, Fig. $\left.11 \mathrm{~d}\right)$ the model would predict temperatures higher by up to $25 \mathrm{~K}$ compared to the original model in the northern and eastern parts, where the upper crystalline crust is cropping out. For the positive thermal anomalies in the basin the model would predict temperatures $15 \mathrm{~K}$ higher than the original model, whereas the negative thermal anomaly in the southeast of Munich is less affected.

The sensitivity analysis has shown that the thermal conductivity of the Alpine Body as well as the thermal conductivity and the radiogenic heat production of the upper crystalline crust have the strongest impact on the basin-wide conductive thermal field. While the thermal conductivity of the Tauern Body shows a smaller influence on the temperature distribution in the Molasse Basin, the thermal conductivity of the lower crystalline crust has only a minor influence on the basin-wide thermal field. Both properties of the Molasse Sediments, the Upper Jurassic and the PreMalm Sediments, show no significant influence on the thermal field within the range of values tested (Table 2) and are, therefore, not further described.

\section{Interpretation and discussion}

Analysing the calculated 3D thermal field, different thermal effects can be recognized affecting the deep temperature distribution in the Molasse Basin area. Regional effects affecting the deeper part of the system and local effects having the strongest influence on the shallow thermal field can be distinguished.

\section{Regional thermal effects}

One regional effect is caused by the average geothermal gradient due to the depth of the thermal LAB. Where the LAB is shallower, as in the northern and northwestern model parts, the heat has to overcome a smaller distance to equilibrate between the two thermal boundaries (LAB: $1300{ }^{\circ} \mathrm{C}$, surface: -11 to $+12{ }^{\circ} \mathrm{C}$ ) leading to an increased geothermal gradient than in areas with a deeper LAB (central model area). The switch of the bending direction of the isotherms in the mantle in the central model part from bend upwards (increasing geothermal gradient) to bend downwards (decreasing geothermal gradient) is thereby credited to the increasing depth of the LAB towards the south. Interestingly, the geothermal gradient is not smallest in the area of the Alps where the LAB is deepest, but higher than in the basin area. This is related to the compensating effect of crustal thickness. The crystalline crust and the Tauern Body produce radiogenic heat adding to the total heat budget and is thinner below the Alpine foreland than below and within the orogen. 
A second regional effect can be connected to the radiogenic heat production in the crust, which is an additional heat source in the system and much higher in the upper crystalline crust than in the rest of the model layers. Since the absolute amount of produced heat is dependent on the crustal volume, the intensity of this effect is in close correlation to the thickness of the upper crystalline crust, which varies between 20 and $28 \mathrm{~km}$ thickness in the northern model part. In contrast, below the Alpine area and the Molasse Basin the upper crystalline crust is far thinner and may locally be only $6 \mathrm{~km}$ thick. The Tauern Body consists predominantly of upper crystalline material and thus also represents a domain with high radiogenic heat production. Accordingly, the heat budget within the Tauern Body is larger than that in the surrounding domain where the radiogenic upper crust is thinner (Fig. 4c). This causes higher temperatures in the lower part of the Tauern Body compared to its neighbouring areas (Fig. 7b). Therefore, in spite of a uniform depth of the thermal LAB, lateral variations in temperature evolve in the upper part of the lithospheric mantle and the lower part of the crust illustrated by upward-curved isotherms in Fig. $7 \mathrm{~b}$.

A third thermal effect affecting the thermal field on a regional scale is the contrast in the thermal conductivity between the highly conductive crystalline crust and the Tauern Body and the less conductive sediments. In areas where crystalline material is exposed to the surface, as in the Tauern Window (Schmid et al. 2004a), heat can escape more efficiently than in areas covered by insulating sediments. This effect is known as chimney effect (Fig. 7b) and can be observed as downward-bent isotherms inside the shallow Tauern Body and as lower shallow temperatures in the area of the Tauern Body compared to the surrounding area in the temperature maps (Fig. 8e, f).

Around the Tauern Window the deformed sediments of the Alpine Body cover the crystalline crust (Fig. 4a). Consisting mostly of limestone, dolomite, marl and clay, the Alpine Body has a far smaller heat conductivity than the underlying crystalline crust and the crystalline Tauern Body. Thus, the heat generated in the crust and mantle is trapped by the low conductive sediments of the Alpine Body which causes heat storage in the sediments. This effect is known as blanketing effect (Fig. 7a) and is stronger where the sediments are thicker (as in the Alps and the basin) and weaker where sedimentary thickness is smaller (as in the north of the model). Such a blanketing effect can also be recognized in the fill of the Molasse Basin, where calcareous and clastic sediments overlie the crystalline crust. This thermal blanketing leads to increasing temperatures from north to south in the Molasse Basin (Figs. 8, 9) and correlates with the increasing thickness of Molasse Sediments from north to south (Fig. 3c).

The chimney effect and thermal blanketing are thus results of heat refraction in response to contrasts in thermal conductivity. Such phenomena have already been described for other basins in different tectonic settings (Bayer et al. 1997; Allen and Allen 2005; Stephenson et al. 2009; Noack et al. 2010; Cherubini et al. 2014) and are laterally influencing each other. For the Alps and the Molasse Basin this implies that the heat coming from the asthenosphere together with the heat generated in the crystalline crust arrives at the base of the insulating sediments of the Alpine Body and the Molasse Basin, is stored within the sediments and causes higher temperatures within the latter. In areas where the heat is conducted directly to the surface, as within the Tauern Body, lower shallow temperatures evolve than in the surrounding areas. In summary, 
the binary division of the model area into a cooler northern part and a warmer southern part with a transition at the northern rim of the Molasse Basin is in close correlation with the distribution of sedimentary thicknesses (Figs. 3, 4), but additionally influenced by the thickness of the conductive crystalline crust and the amount of radiogenic heat created in its upper part.

In addition, topographic features may have an effect on local subsurface temperatures which has already been quoted by Kutasov (1999) and Noack et al. (2010). In topographically high areas (e.g. summits of the Alps) the upper thermal boundary condition is prescribed at higher elevation than in topographically low areas (e.g. valleys of the Alps). This difference in elevation can reach up to $2 \mathrm{~km}$. Accordingly, a temperature variation evolves in the upper few kilometres that correlates spatially with the topography. Even considering 3D heat transport such a topographic effect on the temperature distribution can be traced downwards to upper crustal levels, causing local short-wavelength temperature anomalies in the shallow thermal field. In the deeper crust the influence of topographic effects is lost and the depth to the thermal LAB dominates the evolving temperature pattern.

The superposition of all three described effects (topographic effect, blanketing effect and chimney effect) leads to a characteristic lateral temperature distribution in the Molasse Basin area with a stronger variation (Fig. 8, 9) than in the temperature maps created by 3D interpolation of measured values (Agemar et al. 2014b). This is due to the implemented structural heterogeneity considered in the thermal model of this study compared to the interpolation between measured data points in the GeotIS project (Agemar et al. 2014b) assuming a homogeneous and isotropic configuration of the subsurface. However, Agemar et al. (2012) recommend treating the deeper temperature estimates of the thermal model of GeotIS with extra care due to possible local effects on the temperature distribution caused by a heterogeneous distribution of thermal conductivities, which have not been regarded in the temperature interpolation.

\section{Comparing with measured temperatures}

Assuming heat conduction being the main heat transport mechanism in the Molasse Basin, the observed temperature pattern and the temperature values have been reproduced to a certain degree in this study. Compared to the results of the GeotIS project (Agemar et al. 2014b) our model is too warm in the upper $5000 \mathrm{~m}$ bsl. Also, the temperatures predicted in our model are too warm if compared to published temperatures measured at 24 geothermal production sites. As illustrated in Fig. 6, 12 sites are showing temperature differences in a range of $\pm 10 \mathrm{~K}$, a value as high as the standard deviation of bottom hole temperatures and temperature logs (Hermanrud et al. 1990; Förster 2001; Noack et al. 2010; Agemar et al. 2012, 2014a). At further 5 locations the model results show temperature difference of more than $+10 \mathrm{~K}$ in the area of the described negative thermal anomaly southeast of Munich, which is less cold in the model than observed. In this area, an additional effect on the thermal field by heat transport related to fluid flow is considered likely (Birner 2013). Such a phenomenon has already been assumed for the western Molasse Basin by Rühaak et al. (2010), for a similar setting with a the deep carbonate aquifer in the Po Plain in Italy (Pasquale et al. 2013), and for other structural 
settings as the North German Basin by Noack et al. (2010) and the Western Canada Sedimentary Basin (Majorowicz et al. 2014).

For seven locations, the modelled temperatures are too cold compared to the measured values. One of these locations is Windischeschenbach, where the difference between modelled and observed temperature is largest ( $>65 \mathrm{~K}$ at $8638 \mathrm{~m} \mathrm{bsl}$ ). A possible reason for such a high temperature difference may lie in local heterogeneities of the radiogenic heat production and thermal conductivity in the crust, which are not resolved in our model or advective heat transport related to fluid flow, which is not considered in our approach.

In addition, the influences of large faults zones permeable for fluid are not considered in our approach. Such fault zones may act as pathways for fluid flow and enable convective heat transport in the basin. To investigate a potential influence of fluid flow related cooling on the thermal field of the Molasse Basin area a coupled transport of fluid and heat should be considered. However, a higher vertical and horizontal resolution than that used for this study and the implementation of faults into the model would be needed, which in turn would require an improved structural and (hydro)geological database.

\section{Sensitivity}

We admit that the limited model resolution and the assignment of homogenous parameters to the layers are likely to be a source of error in our approach. However, a sensitivity analysis (Figs. 10,11) addressing the impact of different lithostratigraphic units and their, respectively, assigned thermal properties on the geothermal field has shown that the lithospheric-scale thermal field mostly depends on the depth of the LAB, the configuration of the crystalline crust and the thermal properties of the Alpine and Tauern Body as well as the thickness of the Molasse Sediments. Of these, especially the radiogenic heat production of the upper crystalline crust shows a large a priori uncertainty related to the assigned values for radiogenic heat production (Vosteen et al. 2006; Vilá et al. 2010) due to lacking measurements. Variations in the thermal properties of the Nördlinger Ries, the Folded Molasse Sediments, Cretaceous, the Upper Jurassic Malm and the PreMalm Sediments have shown only minor influences on the long-wavelength thermal field as these layers are of limited thickness and partly even discontinues. Nevertheless, a better representation of the real geological situation could be achieved by implementing varying thermal properties laterally and with depth within a model unit. Recent studies (Homuth et al. 2014, 2015) on the nature and distribution of thermal properties of the Upper Jurassic could help reducing the uncertainties further. However, the findings for the long-wavelength thermal field of the Molasse Basin area and the thermal interdependence between the basin and the Alps are robust. Prescribing laterally varying thermal properties to the model units would lead to short-wavelength thermal effects and thus not change the regional pattern of temperature distribution significantly.

\section{Prominent isotherms}

Given the mentioned limitations, the results nevertheless indicate that assuming conductive heat transport as the first-order control for the thermal field is valid and give first-order estimates of deep temperature variations. According to the calculated depth 
of the $100{ }^{\circ} \mathrm{C}$ isotherm (Fig. 9c), temperatures high enough for both geothermal heating and electric power production can be found at deeper levels in the north of the model area than in the south, due to the thickness distribution of the Molasse Sediments. Within the Molasse Basin this isotherm is at an average depth of $2000 \mathrm{~m}$ bsl with small lateral depth variations, a result that supports the suitability of this area for electrical power production.

The second prominent temperature level is the $460^{\circ} \mathrm{C}$ isotherm, which marks the transition between brittle to ductile behaviour of granitic material and thus is a threshold value below which the probability of crustal rupture and associated earthquakes are strongly reduced. The larger depth of this isotherm in the northern part of the model compared to the southern part (Fig. 9d) implies a weaker rheology of the lithosphere at shallower depth below the Alps than below the northern part of the model area. This in turn is consistent with earlier results from thermo-mechanical models of Genser et al. (1996) and Okaya et al. (1996). Moreover, higher temperatures at shallow depths below the Alps (compared to larger depths below the Molasse Basin) would explain the earthquake distribution described by Deichmann et al. (1999), Willingshofer and Cloetingh (2003) and Singer et al. (2014) with deep earthquakes in the foreland and shallow earthquakes in the Alpine area. In fact, the deepest earthquakes shown by Singer et al. (2014) correlate well with the depth of the $460{ }^{\circ} \mathrm{C}$ isotherm predicted by the conductive calculations of this study.

\section{Conclusions}

Assuming conductive heat transport to be the dominate processes, the lithosphericscale 3D thermal field of the Molasse Basin area has been calculated. In the predicted temperature distribution different superposed thermal effects can be recognized, which show an interdependence between the Alps and the foreland basin with respect to the regional thermal field.

Our results indicate that the temperature distribution in the lithospheric mantle and the crystalline crust is controlled by the depth of the thermal LAB, the thickness distribution of the radiogenic crust and contrast in thermal conductivities between crystalline and sedimentary rocks. For the Molasse Basin and the adjacent Alpine orogen, this results in shallow hotter temperature where thick sedimentary rocks cover the crystalline crust (Alpine Body and Molasse Basin) and colder shallower temperatures where the crystalline crust is exposed (Tauern Body). This related chimney effect can have a significant lateral influence in response to 3D heat transport and cause local negative anomalies in neighbouring domains (e.g. southeast of Munich). Together with the topographic effect, the chimney and blanketing effects control the regional-scale temperature distribution in the sedimentary part of the model.

Using a conductive approach, this study was able to reproduce the measured present-day thermal field in the shallow part of the Molasse Basin area to a certain degree. Though the predicted temperatures are in average a few degrees too hot, the predicted temperature trend matches the observed temperature pattern shown by GeotIS. The respective reproduced positive and negative thermal anomalies show that this temperature pattern is caused by the structural configuration of geological units and related contrasts in thermal properties. In particular, sensitivity studies have shown that considering 
the configuration of the crystalline crust and the Tauern Body as well as the Alpine Body is of high significance for the regional thermal field. Lateral variations in the structure and the lateral heterogeneity of thermo-physical properties of the Molasse Sediments and the Mesozoic and Triassic sediments have an additional influence on the temperatures at shallow depth.

The misfit between the measured and calculated temperatures in the sediments is interpreted to be caused by additional advective and convective heat transport, mechanisms not considered in this study. To test if fluid flow related cooling is as significant for the creating of the thermal anomalies as the structural configuration, coupled fluid and heat transport simulations are required. The conductive model of this study may suit as a starting point and provide lower thermal boundary conditions for the deeper, conductive dominated parts of such coupled simulations.

\section{Authors' contributions}

AMP constructed the mentioned 3D models, calculated the thermal field and drafted the manuscript. MSW helped to draft the manuscript. MSW and MSC participated in the design of the study and contributed with fruitful discussions to the interpretation of the results. All authors read and approved the final manuscript.

\section{Author details}

${ }^{1}$ Department 4 Chemistry and Material Cycles, Section 4.4 Basin Analysis, German Research Centre for Geoscience GFZHelmholtz Centre Potsdam, Telegrafenberg, 14473 Potsdam, Germany. ${ }^{2}$ Faculty of Georesources and Material Engineering, Institute of Geology and Geochemistry of Petroleum and Coal, RWTH Aachen, Templergraben 55, 52062 Aachen, Germany. ${ }^{3}$ Institute of Geological Sciences-Hydrogeology Group, Freie Universität Berlin, Malteserstraße 74-100, 12249 Berlin, Germany.

\section{Acknowledgements}

This study has been funded by and carried out at the German Research Centre for Geosciences GFZ_Helmholtz Centre Potsdam in cooperation with the Freie University of Berlin and supported by the LfU Bavaria, the LIAG Hannover and LRGB Freiburg by providing the required data.

\section{Compliance with ethical guidelines}

Competing interests

The authors declare that they have no conflict of interest.

Received: 12 June 2015 Accepted: 3 September 2015

Published online: 12 September 2015

\section{References}

Agemar T, Schellschmidt R, Schulz R. Subsurface temperature distribution in Germany. Geothermics. 2012;44:65-77. doi:10.1016/j.geothermics.2012.07.002.

Agemar T, Weber J, Schulz R. Deep geothermal energy production in Germany. Energies. 2014a;7:4397-416. doi:10.3390/ en7074397.

Agemar T, Alten J-A, Ganz B, Kuder J, Kühne K, Schumacher S, Schulz R. The geothermal information system for Germany-GeotIS. Zeitschrift der Deutschen Gesellschaft für Geowissenschaften. 2014b;165(2):129-44.

Allen and Allen. Basin analysis: principles and applications. 2nd edn. Australia: Wiley-Blackwell; 2005.

Bachmann GH, Dohr G, Müller M. Exploration in a classic thrust belt and its foreland: Bavarian Alps. Germany Am Assoc Pet Geol Bull. 1982;66:2529-42.

Bayer U, Scheck M, Koehler M. Modeling of the 3-D thermal field in the northeast German Basin. Geol Rundsch. 1997:86:241-51.

Berge TB, Veal SL. Structure of the Alpine foreland. Tectonics. 2005; . doi:10.1029/2003TC001588.

Bianchi I, Miller MS, Bokelmann G. Insights on the upper mantle beneath the Eastern Alps. Earth Planet Sci Lett. 2014;403:199-209. doi:10.1016/j.epsl.2014.06.051.

Birner J, Mayr C, Thomas L, Schneider M, Baumann T, Winkler A. Hydrochemie und Genese der tiefen Grundwässer des Malmaquifers im bayerischen Teil des süddeutschen Molassebeckens. Z Geol Wiss. 2011;39:291-308.

Birner J, Fritzer T, Jodocy M, Savvatis A, Schneider M, Stober I. Hydraulische Eigenschaften des Malmaquifers im Süddeutschen Molassebecken und ihre Bedeutung für die geothermische Erschließung. Z Geol Wiss. 2012;40:133-56.

Birner J. Hydrogeologisches Modell des Malmaquifers im Süddeutschen Molassebecken. Dissertation, Freie University Berlin; 2013.

Böhm F, Birner J, Steiner U, Koch R, Sobott R, Schneider M, Wand A. Tafelbankiger Dolomit der Kernbohrung Moosburg SC4: Ein Schlüssel zum Verständnis der Zuflussraten in Geothermiebohrungen des Malmaquifers (Östliches MolasseBecken; Malm Gamma—Zeta; Süddeutschland). Z Geol Wiss. 2011;39(2):117-57. 
Brückl E, Behm M, Decker K, Grad M, Guterch A, Keller GR, Thybo H. Crustal structure and active tectonics in the Eastern Alps. Tectonics. 2010;. doi:10.1029/2009TC002491.

Brückl E. Lithospheric Structure and Tectonics of the Eastern Alps_evidence from new seismic data, Tectonics, Dr. Damien Closson (ed.). ISBN: 978-953-307-545-7, InTech; 2011. doi:10.5772/14364.

Cacace M, Blöcher G, Watanabe N, Moeck I, Börsing N, Scheck-Wenderoth M, Kolditz O, Huenges E. Modelling of fractured carbonate reservoirs: outline of a novel technique via a case study from the Molasse Basin, southern Bavaria, Germany. Environ Earth Sci. 2013;70:3585-602. doi:10.1007/s12665-013-2402-3.

Cherubini Y, Cacace M, Scheck-Wenderoth M, Noack V. Influence of major fault zones on 3-D coupled fluid and heat transport for the Brandenburg region (NE German Basin). Geotherm Energy Sci. 2014;2:1-20. doi:10.5194/ gtes-2-1-2014.

Clauser C. Thermal storage and transport properties of rocks, I: heat capacity and latent heat. In: Gupta H, editor. Encyclopedia of solid earth geophysics. Heidelberg: Springer; 2011 a.

Clauser C. Radiogenic heat production of rocks. In: Gupta H, editor. Encyclopedia of solid earth geophysics. Heidelberg: Springer; $2011 \mathrm{~b}$

Deichmann N, Baer M, Braunmiller J, Ballarin D, Bay F, Delouis B, Fäh D, Giardini D, Kastrup U, Kind F, Kradolfer U, Künzle W, Röthlisberger S, Schler T, Salichon J, Sellami S, Spühler E, Wiemer S. Earthquakes in Switzerland and surrounding regions during 1999. Eclogae Geol Helv. 1999;93:395-406.

Dragoni M. The brittle-ductile transition in tectonic boundary zones. Ann Geophys. 1993;: doi:10.4401/ag-4282.

DWD. 2013. https://werdis.dwd.de/.

Ebbing J. 3-D Dichteverteilung und isostatisches Verhalten der Lithosphäre in den Ostalpen. Dissertation, Freie University Berlin; 2002

Ebbing J. The crustal structure of the Eastern Alps from a combination of 3D gravity modelling and isostatic investigations. Tectonophysics. 2004;380:89-104. doi:10.1016/j.tecto.2003.12.002.

Ebbing J, Braitenberg C, Götze H-J. The lithospheric density structure of the Eastern Alps. Tectonophysics. 2006;414:14555. doi:10.1016/j.tecto.2005.10.015.

Ernstson K, Pohl J. Neue Modelle zur Verteilung der Dichte und Geschwindigkeit im Ries-Krater. Geol Bavar. 1977;75:355-71.

Förster A. Analysis of borehole temperature data in the Northeast German Basin: continuous logs versus bottom-hole temperatures. Pet Geosci. 2001;7:241-54.

Freudenberger W, Schwerd K. Geological Map of Bavaria $(1: 500,000)$ and its explanations. Munich: Bavarian Geological Survey; 1996.

Gebrande H, TRANSALP Working Group. TRANSALP: concept and main results on the project. Geologisch-Paläontologischen Mitteilungen. 2001;25:7-8, Innbruck.

Geissler WH, Sodoudi F, Kind R. Thickness of the central and eastern European lithosphere as seen by $\mathrm{S}$ receiver functions. Geophys J Int. 2010;181:604-34. doi:10.1111/j.1365-246X.2010.04548.x.

Genser J, van Wees JD, Cloething S, Neubauer F. Eastern Alpine tectono-metamorphic evolution: constraints from twodimensional P-T-t modelling. Tectonics. 1996;15:584-604. doi:10.1029/95TC03289.

Team GeoMol. GeoMol_assessing subsurface potentials of the Alpine Foreland Basins for sustainable planning and use of natural resources_-Project Report. Augsburg: Bavarian Environment Agency; 2015.

Grad M, Tiira T, ESC Working Group. The Moho depth map of the European Plate. Geophys J Int. 2009;176:279-92. doi:10.1111/j.1365-246X.2008.03919.x.

GTV. 2014. http://www.geothermie.de/wissenswelt/geothermie/in-deutschland.html.

Handy MR, Rosenberg CL. From embryonic tectonics and geosynclines to modern concepts of rifting, spreading, and Alpine orogenesis: a summary of contributions to the 9th Alpine Workshop (Cogne, 2009). Int J Earth Sci. 2011;100:895-7. doi:10.1007/s00531-011-0647-1.

Hermanrud C, Cao S, Lerche I. Estimates of virgin rock temperature derived from BHT measurements: bias and error. Geophysics. 1990;55:924-31.

HISTALP. 2013. http://www.zamg.ac.at/histalp/.

Hrubcová P, Špičák A, Švancara J, Rủžek B, Hubatka F, Tomášková A, Brož M. Investigation of the Deep Structure of the Bohemian Massif CELEBRATION 2000. CR: MS Ministry of Environment; 2002.

Homuth S, Götz AE, Sass I. Lithofacies and depth dependency of thermo- and petrophysical rock parameters of the Upper Jurassic geothermal carbonate reservoirs of the Molasse Basin. Zeitschrift der Deutschen Gesellschaft für Geowissenschaften. 2014;165(3):469-86. doi:10.1127/1860-1804/2014/0074.

Homuth S, Götz AE, Sass I. Physical Properties of the geothermal carbonate reservoirs of the Molasse Basin, GermanyOutcrop Analogue vs. Reservoir Data. World geothermal congress 2015, 19.04-24.04.2015, Melbourne, Australia (accepted); 2015.

InMeteo. 2013. http://www.in-pocasi.cz/archiv/img/teplotap2a.png.

ITG. 2014. http://www.tiefegeothermie.de/projekte/garching.

Jankowski. Die Postimpakt Sedimente in der Forschungsbohrung Nördlingen 1973. Geologica Bavarica. 1977;75:21-36.

Jodocy M, Stober I. Geologisch-geothermische Tiefenprofile für den südwestlichen Teil des Süddeutschen Molassebeckens. Zeitschrift der Deutschen Gesellschaft für Geowissenschaften. 2009;160(4):359-66. doi:10.1127/1860-1804/2009/0160-0359.

Karousova H, Plomerova J, Babuska V. Upper-mantle structure beneath the southern Bohemian Massif and its surroundings imaged by high-resolution tomography. Geophys J Int. 2013;194:1203-15. doi:10.1093/gji/ggt159.

Kempf O, Matter A, Burbank DW, Mange M. Depositional and structural evolution of a foreland basin margin in a magnetostratigraphic framework: the eastern Swiss Molasse Basin. Int J Earth Sci. 1999;88:253-75. doi:10.1007/ s005310050263.

Koch A, Jorand R, Arnold J, Pechnig R, Mottaghy D, Vogt C, Clauser C. Erstellung statistisch abgesicherter thermisches und hydraulischer Gesteinseigenschaften für den flachen und tiefen Untergrund in Deutschland. Phase 2-Westliches Nordrhein Westfalen und bayerisches Molassebecken. Schlussbericht zum BMU-Projekt FKZ 0327563, E.ON Energy Research Center, RWTH Aachen University, Germany; 2009. 
Kutasov IM. Applied geothermics for petroleum engineers. Netherlands: Elsevier Science B.V; $1999 \mathbf{3 4 7}$ pp Landolt-Börnstein. Zahlenwerte und Funktionen aus Naturwissenschaft und Technik, vol. 1a. Berlin: Springer; 1982. Lemcke K. Zur nachpermischen Geschichte des nördlichen Alpenvorlandes. Geol Bavar. 1973;69:5-48.

Majorowicz J, Nieuwenhuis G, Unsworth M, Phillips J, Verveda R. High temperatures predicted in the granitic basement of northwest Alberta-an assessment of the EGS energy potential. In: Proceedings of 39th workshop on geothermal reservoir engineering Stanford University, Stanford California, SGP-TR-202. 2014.

Marotta AM, Splendore R. 3D mechanical structure of the lithosphere below the Alps and the role of the gravitational body forces in the regional present-day stress field. Tectonophysics. 2014;631:117-29. doi:10.1016/j. tecto.2014.04.038

Mitterbauer U, Behm M, Brückl E, Lippitsch R, Guterch A, Randy Keller G, Koslovskaya E, Rumpfhuber E-M, Sumanovac F. Shape and origin of the East-Alpine slab constrained by the ALPASS teleseismic model. Tectonophysics. 2011;510:195-206. doi:10.1016/j.tecto.2011.07.001.

Noack V, Cherubini Y, Scheck-Wenderoth M, Lewerenz B, Höding T, Simon A, Moeck I. Assessment of the present-day thermal field (NE German Basin)_inferences from 3D modelling. Geochemistry. 2010;70(3):47-62. doi:10.1016/j. chemer.2010.05.008.

Okaya N, Cloething S, St Mueller. A lithospheric cross-section through the Swiss Alps—II. Constraints on the mechanical structure of a continent-continent collision zone. Geophys J Int. 1996;127:399-414. doi:10.1111/j.1365-246X.1996. tb04729.x.

Pamer RFJ, Diepolder GW. 3D geological modelling in Bavaria-state-of-the-art at a state geological survey. Zeitschrift der Deutschen Gesellschaft für Geowissenschaften. 2010;161(2):189-203. doi:10.1127/1860-1804/2010/0161-0189.

Pasquale V, Chiozzi P, Verdoya M. Evidence for thermal convection in the deep carbonate aquifer of the eastern sector of the Po Plain, Italy. Tectonophysics. 2013;594:1-12. doi:10.1016/j.tecto.2013.03.011.

Pasternak M. Exploration und Produktion von Erdöl und Erdgas in Deutschland 2014. Erdöl Erdgas Kohle. 2015;131(7):258-77.

Przybycin AM, Scheck-Wenderoth M, Schneider M. Assessment of the isostatic state and the load distribution of the European Molasse basin by means of lithospheric-scale 3D structural and 3D gravity modelling. Int J Earth Sci. 2015;104(5):1405-24. doi:10.1007/s00531-014-1132-4.

Ranalli G. Rheology of the earth. 2nd ed. London: Chapman and Hall; 1995.

Reischenbacher D, Sachsenhofer RF. Entstehung von Erdgas in der oberösterreichischen Molassezone: daten und offene Fragen. BHM Berg Huettenmaenn Monatsh. 2011;156(11):463-8. doi:10.1007/s00501-011-0037-9.

Roeder D, Bachmann GH. Evolution, structure and petroleum geology of the German Molasse Basin. In: Ziegler P, Horvath F (eds) Peri-Tethys Memoir 2: structure and prospects of Alpine Basins and Forelands. Memoires Museum National d'Histoire Naturelle. 1996:170:263-284, Editions du Museum National d'Histoire Naturelle, Paris, France.

Rupf I, Nitsch E. Das Geologische Landesmodell von Baden-Württemberg—Datengrundlagen, technische Umsetzung und erste geologische Ergebnisse. LGRB-Informationen 21. Freiburg; 2008.

Rühaak W. Multidimensional modeling of the thermal and flow regime in the western part of the Molasse Basin, Southern Germany. Dissertation, Rheinisch-Westfälische Technische Hochschule Aachen; 2009.

Rühaak W, Rath V, Clauser C. Detecting thermal anomalies within the Molasse Basin, southern Germany. Hydrogeol J. 2010;18(8):1897-915.

Rühaak W. 3-D interpolation of subsurface temperature data with measurement error using kriging. Environ Earth Sci. 2015;73(4):1893-900. doi:10.1007/s12665-014-3554-5.

Sachsenhofer RF, Gratzer R, Tschelaut W, Bechtel A. Characterisation of non-producible oil in Eocene reservoir sandstones (Bad Hall Nord field, Alpine Foreland Basin, Austria). Mar Pet Geol. 2006;23(1):1-15.

Scheck M, Bayer U. Evolution of the Northeast German Basin-inferences from a 3D structural model and subsidence analysis. Tectonophysics. 1999;313:145-69. doi:10.1016/S0040-1951(99)00194-8.

Scheck M, Bayer U, Lewerenz B. Salt redistribution during extension and inversion inferred from 3D backstripping. Tectonophysics. 2003;373:55-73. doi:10.1016/S0040-1951(03)00283-X.

Schmid SM, Fügenschuh B, Kissling E, Schuster R. Tectonic map and overall architecture of the Alpine orogen. Ecol Geol Helv. 2004a;97:93-117. doi:10.1007/s00015-004-1113-x.

Schmid S, Fügenschuh B, Kissling E, Schuster R. TRANSMED transects IV, V and VI: three lithospheric transects across the Alps and their forelands. In: Cavazza W, Roure F, Spakman W, Stampfli GM, Ziegler PA (eds) The TRANSMED Atlas: The Mediterranean Region from Crust to Mantle. Springer Verlag; 2004b.

Schmid S, Bernoulli D, Fügenschuh B, Matenco L, Schefer S, Schuster R, Tischler M, Ustaszewski K. The Alpine-CarpathianDinaridic orogenic system: correlation and evolution of tectonic units. Swiss J Geosci. 2008;101:139-83. doi:10.1007/ s00015-008-1247-3.

Schulz R, Agemar T, Alten J-A, Brunken, J, Heber M, Kuder J, Kühne K, Maul A-A, Pester S, Schönhofer K, Fritzer T, Birner J, Schneider M, Rauppach K, Seibt P, Wolfgramm M, Brandes J, Feldrappe H, Obst K, Jodocy M, Stober I. Aufbau eines geothermischen Informationssystems für Deutschland (Endbericht BMU Forschungsvorhaben 0327542), LIAG Archiv-Nr.: 0128452: 114 S, Hannover; 2009

Schulz R, Thomas R, Dussel M, Lüschen E, Wenderoth F, Fritzer T, Birner J, Schneider M, Wolfgramm M, Bartels J, Huber B, Megies T, Wassermann J. Geothermische Charakterisierung von karstig-klüftigen Aquiferen im Großraum München (Endbericht-BMU Forschungsvorhaben 0325013A). LIAG Archiv-Nr. 0130392: 98 S, Hannover; 2012.

Seiberlich CKA, Ritter JRR, Wawerzinek B. Topography of the lithosphere-asthenosphere boundary below the Upper Rhine Graben Rift and the volcanic Eifel region, Central Europe. Tectonophysics. 2013;603:222-36. doi:10.1016/j. tecto.2013.05.034.

Singer J, Diehl T, Husen S, Kissling E, Duretz T. Alpine lithosphere slab rollback causing lower crustal seismicity in northern foreland. Earth Planet Sci Lett. 2014;397:42-56.

Stephenson R, Egholm D, Nielsen SB, Stovba SM. Role of thermal refraction in localizing intraplate deformation in southeastern Ukraine. Nat Geosci. 2009;2:290-3. doi:10.1038/ngeo479.

StMWIT. Bayerischer Geothermieatlas. Bayerisches Staatsministerium für Wirtschaft, Infrastruktur, Verkehr und Technologie München; 2010. 
Tesauro M. An integrated study of the structure and thermomechanical properties of the European lithosphere. Dissertation, Vrije University Amsterdam; 2009.

Thomas R, Schwerd K, Bram K, Fertig J. Shallow high-resolution seismics and reprocessing of industry profiles in southern Bavaria: the Molasse and the northern Alpine front. Tectonophysics. 2006;41:87-96.

Vilá M, Fernández M, Jiménez-Munt I. Radiogenic heat production variability of some common lithological groups and its significance to lithospheric thermal modeling. Tectonophysics. 2010;490:152-64. doi:10.1016/j.tecto.2010.05.003.

Vosteen H-D. The thermal regime of the Eastern Alps along the TRANSALP project. Dissertation, Rheinisch-Westfälischen Technischen Hochschule Aachen; 2003.

Werner J. Die Thermalwasserbohrung Saulgau (Württemberg). Abh Geol Langesamt Baden-Württemberg. 1978;8:129-164

Willingshofer E, Cloetingh S. Present-day lithospheric strength of the Eastern Alps and its relationship to neotectonics. Tectonics. 2003;22:1075. doi:10.1029/2002TC001463.

Submit your manuscript to a SpringerOpen ${ }^{\circ}$ journal and benefit from:

- Convenient online submission

- Rigorous peer review

- Immediate publication on acceptance

- Open access: articles freely available online

- High visibility within the field

- Retaining the copyright to your article

Submit your next manuscript at $\mathbf{s p r i n g e r o p e n . c o m ~}$ 